\title{
PLEISTOCENE DEPOSITS IN THE SOUTHERN EGYPTIAN SAHARA: LITHOSTRATIGRAPHIC RELATIONSHIPS OF SEDIMENTS AND LANDSCAPE DYNAMICS AT BIR TARFAWI
}

\author{
Christopher L. Hill ${ }^{1}$, Romuald Schild ${ }^{2}$ \\ ${ }^{1}$ Departments of Anthropology and Geosciences, Environmental Studies and Ecology, Evolution and Behavior Programs, \\ 1143 Environmental Research Building, 1910 University Drive, Boise State University, Boise, Idaho, 83725-1950, United \\ States; e-mail: chill2@boisestate.edu \\ ${ }^{2}$ Institute of Archaeology and Ethnology, Polish Academy of Sciences, Al. Solidarności 105, 00-140 Warsaw, Poland; \\ e-mail: romuald.schild@gmail.com
}

\begin{abstract}
The sedimentological and lithostratigraphic record from north-central Bir Tarfawi documents the presence of Pleistocene basin-fill deposits. Three topographic basins were created as a result of deflation during climate episodes associated with lowering of the local groundwater table. In each case, the three deflational basins or topographic depressions were subsequently filled with sediments; these basin aggradations coincided with changes from arid climate conditions to wetter conditions and a rise in the groundwater table. The oldest and highest sedimentary remnant is associated with Acheulian artifacts and may reflect spring-fed pond and marsh conditions during a Middle Pleistocene wet climate episode. Lithofacies for a lower stratigraphic sequence (the "White Lake") documents deposition in a perennial lake that varied in extent and depth and is associated with Middle Paleolithic artifacts. A third episode of deflation created a topographic low that has been filled with Late Pleistocene sediments that are associated with Middle Paleolithic artifacts and fossil remains. Lateral and vertical variations in the lithofacies of this basin-fill sequence and the sediments of the "grey-green" lake phases provide a record of changing hydrologic conditions. These hydrologic conditions appear to reflect variations in water-table levels related to groundwater recharge and, at times, local rains.
\end{abstract}

Key words: Sediments, lithofacies, stratigraphy, groundwater, Pleistocene

Manuscript received 10 November 2016, accepted 1 March 2017

\section{INTRODUCTION}

In northeast Africa, the Bir Tarfawi region of the Eastern Sahara preserves a significant sedimentary record of Quaternary environmental change. Bir Tarfawi is located in the southern region of Egypt's Western Desert (Fig. 1) within the northern part of the area described by Bagnold (1933) as the Great Selima Sand Sheet. The sedimentary deposits at Bir Tarfawi are even more remarkable, because the stratigraphic sequences contain vertebrate and invertebrate fossils and Paleolithic artifacts (Wendorf et al., 1993), providing an opportunity to develop hydrologic and climate models based on the integration of sedimentological, geochemical, paleontological, and archaeological data sets. The foundation for understanding the Quaternary geology of this region is based on the studies of Romuald Schild (e.g. Schild and Wendorf, 1981; Schild and Wendorf, 1993).
The goal of this paper is to address questions regarding the nature of environmental and climate change in this region during the Pleistocene by examining and interpreting three sets of basin-fill deposits from the north-central region of Bir Tarfawi. Lithostratigraphic and sedimentological data are applied to examine what might be learned about the water bodies that filled the deflational basins resulting in the deposition of sediments containing fossils and artifacts. The research questions include:

1) What are the sedimentological and stratigraphic characteristics of the Pleistocene deposits in the north-central part of Bir Tarfawi?

2) Can the sedimentary sequences and their topographic/geomorphic context provide information on the size and extent of waterbodies in southern Egypt during the Pleistocene?

3) Do the sediments and fossils provide information 


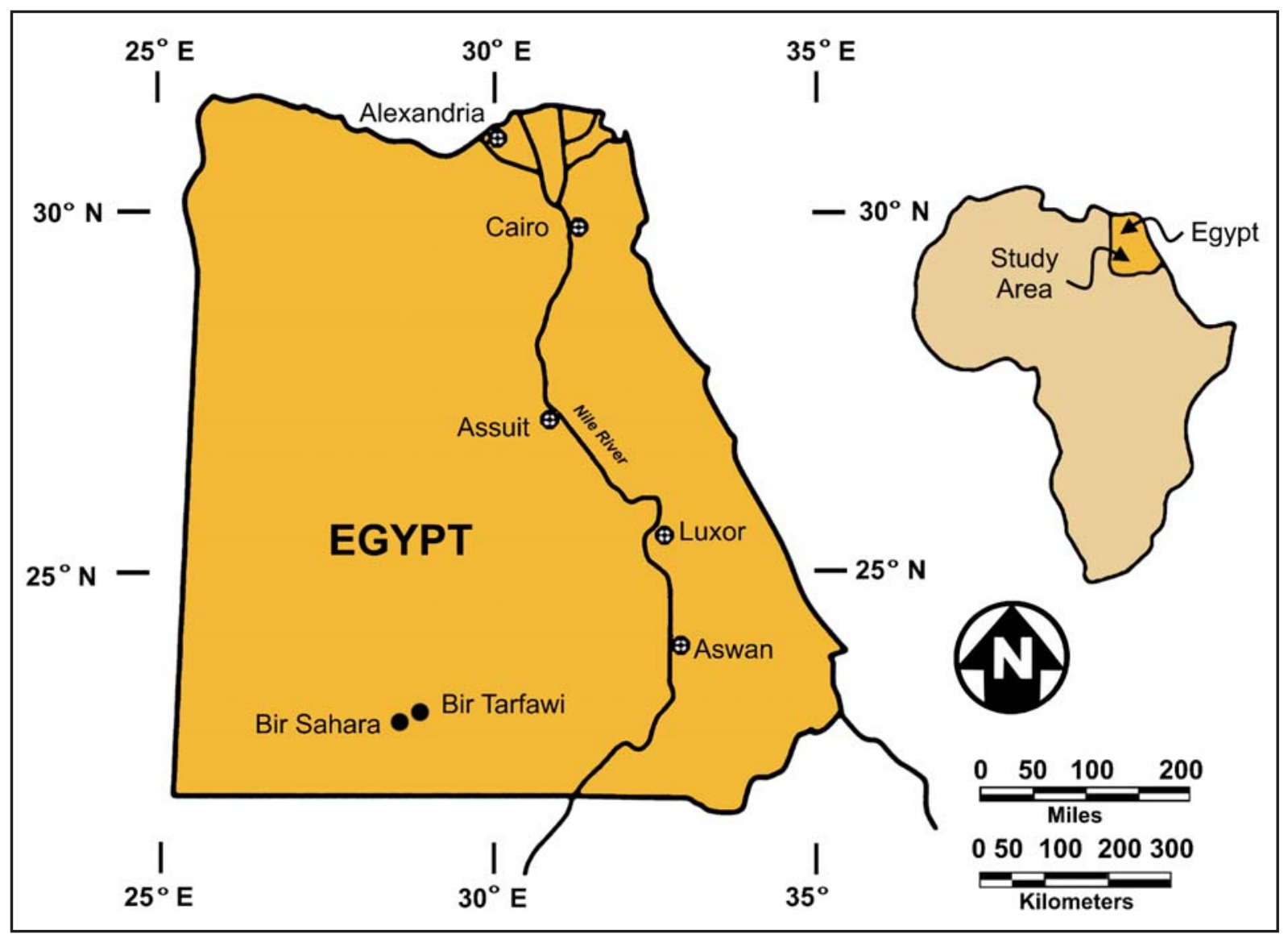

Fig. 1. General location of Bir Tarfawi. Inset map shows location of Egypt in North Africa. See Fig. 2 for a more detailed map of southern Egypt.

on late Quaternary depositional environments and climate change in the region?

The interpretations based on the data from the sedimentary deposits are then used to evaluate various models that have been proposed regarding the nature of hydrologic and environmental conditions within this region of North Africa.

\section{REGIONAL GEOLOGIC AND HYDROLOGIC SETTING}

This part of the Eastern Sahara is the largest hyperarid hot desert region on the Earth. It lies west of Egypt's Eocene Limestone Plateau and the Atmur el Kibeish (south of the Kharga Depression), east of the Gilf Kebir area and south of the Dakhla Oasis depression (Fig. 2). Regionally, the highest elevations are the Gebel Uweinat and the Gilf Kebir Plateau mountain area located in southwestern Egypt and the Limestone Plateau situated to the northeast. The bedrock geology consists of primarily Cretaceous sandstones attributed to either the Nubia, the Abu Ras or the Six Hills Formation which are exposed north of Bir Tarfawi, while some Cretaceous and Paleozoic sandstones occur to the west and south (Issawi, 1978, 1993; Issawi et al., 1999). The oldest rocks are Precambrian basement granites and gneisses of the El Tawila massif (or Tarfawi High) that rise just east of Tarfawi (Richter and Schandelmeier, 1990;
Issawi, 1993). The structural geology of the region may play an important role in the presence of surface groundwater at Bir Tarfawi; it has been proposed that crystalline basement rocks of the Uweinat-Safsaf uplift act as a dam to the north-south migration of groundwater (cf. Klitzch, 1983) and the natural near surface water holes appear to be local reservoirs structurally controlled by bedrock sandstone-igneous interfaces (cf. Tarfawi, Abu El Hussein, Nakhlai) or trapped along the flanks of structural highs (cf. Kiseiba) (Issawi, 1978). In the Tarfawi basin the boundary between younger unconsolidated sand and consolidated Tertiary alluvium is at a depth of about $40 \mathrm{~m}$ below the surface while Cretaceous-age sandstone lies $110 \mathrm{~m}$ below the surface (Behrens et al., 1984).

Calcretes or kankur (concretionary limestone) are found in the northern Selima Sand Sheet (Issawi, 1978) and these surround the deflational basins in the Bir Tarfawi area (Fig. 3). Based on geochemical analyses and microscope observations of the thin-sections, Roper (1993) distinguished groundwater-formed calcretes in this region. Mongenetic calcretes in the Selima Sand Sheet were interpreted as having formed in small lakes or been fed by a high groundwater table. More complex and thicker calcretes are present at Bir Tarfawi (Kropelin, 1993). Pachur et al. (1987) applied the term phreatogenic crust to calcretes formed by either lakes or groundwater in this region. On the surface of the calcretes or kankur (that form the plateau surrounding 


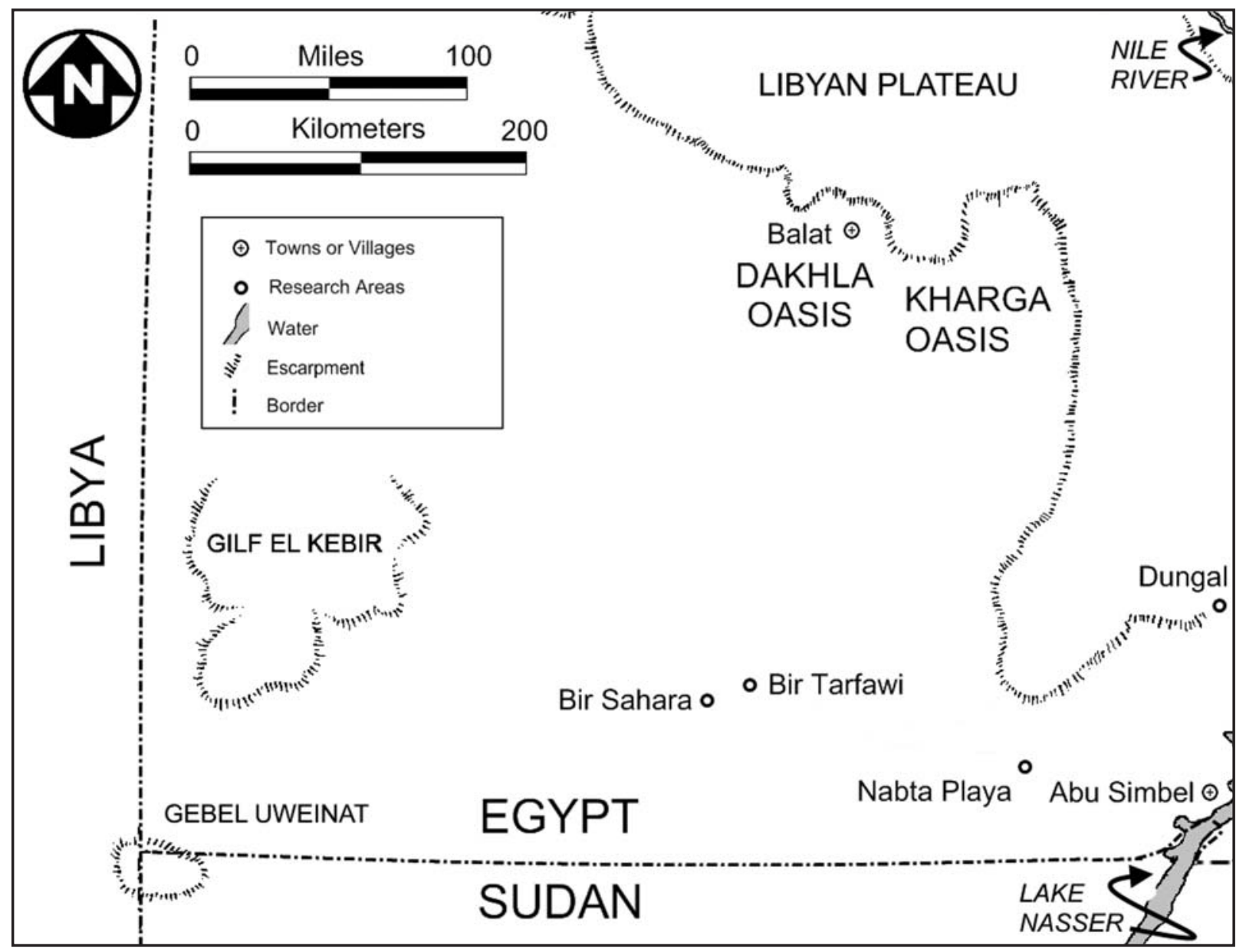

Fig. 2. Location of Bir Tarfawi in southern Egypt.

the deflational basins at Bir Tarfawi) are scattered artifacts that can be taxonomically assigned to the Acheulian, Middle Paleolithic, and Neolithic leading to the conclusion that the plateau-kankur surface has been in existence since at least the Middle Pleistocene. Strata at Bir Tarfawi associated with late Acheulian artifacts have been tentatively correlated with the "Abbassian" pluvials, while sediments associated with Middle Paleolithic artifacts have been assigned to the "Saharan" pluvials (Saharan I = Mousterian, Saharan II = Aterian, Said, 1990: 503).

On the southern end of Bir Tarfawi groundwater is near or at the surface at the present time. Groundwater depth from surface appears to fluctuate seasonally (Kehl, 1987). The elevation for the water-table has been reported as 242 m a.s.l. (Hesse et al., 1987) and 240 and $237 \mathrm{~m}$ a.s.l. (Brinkmann et al., 1987), and has also been measured at less than $239 \mathrm{~m}$ a.s.l. (Schild and Wendorf, 1993). In some places, groundwater can also occur a few cm to a $1 \mathrm{~m}$ below the surface (Aliaily, 1993; Thorweihe and Heinl, 1993). Seepage from this water forms a discontinuous strip of vegetation including palm (Phoenix dactylifera), dom palm trees (Hyphaene thebaica), acacia and tamarix (Tamarix spp.) trees or shrubs. The depth of the groundwater table, along with sediment and geochemistry characteristics, plays an important role in the vegetation of oases in south- ern Egypt and northern Sudan (Kehl, 1987) with Juncus rigidus and $P$. dactylifera present where water is close to or at the surface and Sporobolus spicatus, Alhagi manifera, and Tamarix mannifera present in zones where the water table is deeper below the surface. Kehl (1987) reports that Phragmites australis occur at other oases in the region but is absent at Bir Tarfawi, although Schneider (1993) lists it as present at Tarfawi.

\section{METHODS OF STUDY}

Samples were collected from stratigraphic trenches and related archaeological excavations associated with several different sedimentary remnants connected with Acheulian and Middle Paleolithic artifacts within the Bir Tarfawi deflational depression (Figs 3-5 show the general location of the remnants sampled, while Figs 6-16 show trench and sample locations). The exposed stratigraphic profiles were described and sampled after first cleaning the wall by starting at the top of the exposed profile, then documenting the stratigraphy with a scale drawing (usually at $1 \mathrm{~mm}=$ $1 \mathrm{~cm}, 1: 10$ scale), noting the major features of each sedimentary deposit, and then sampling by starting from the bottom of the exposed section. The characteristics noted 


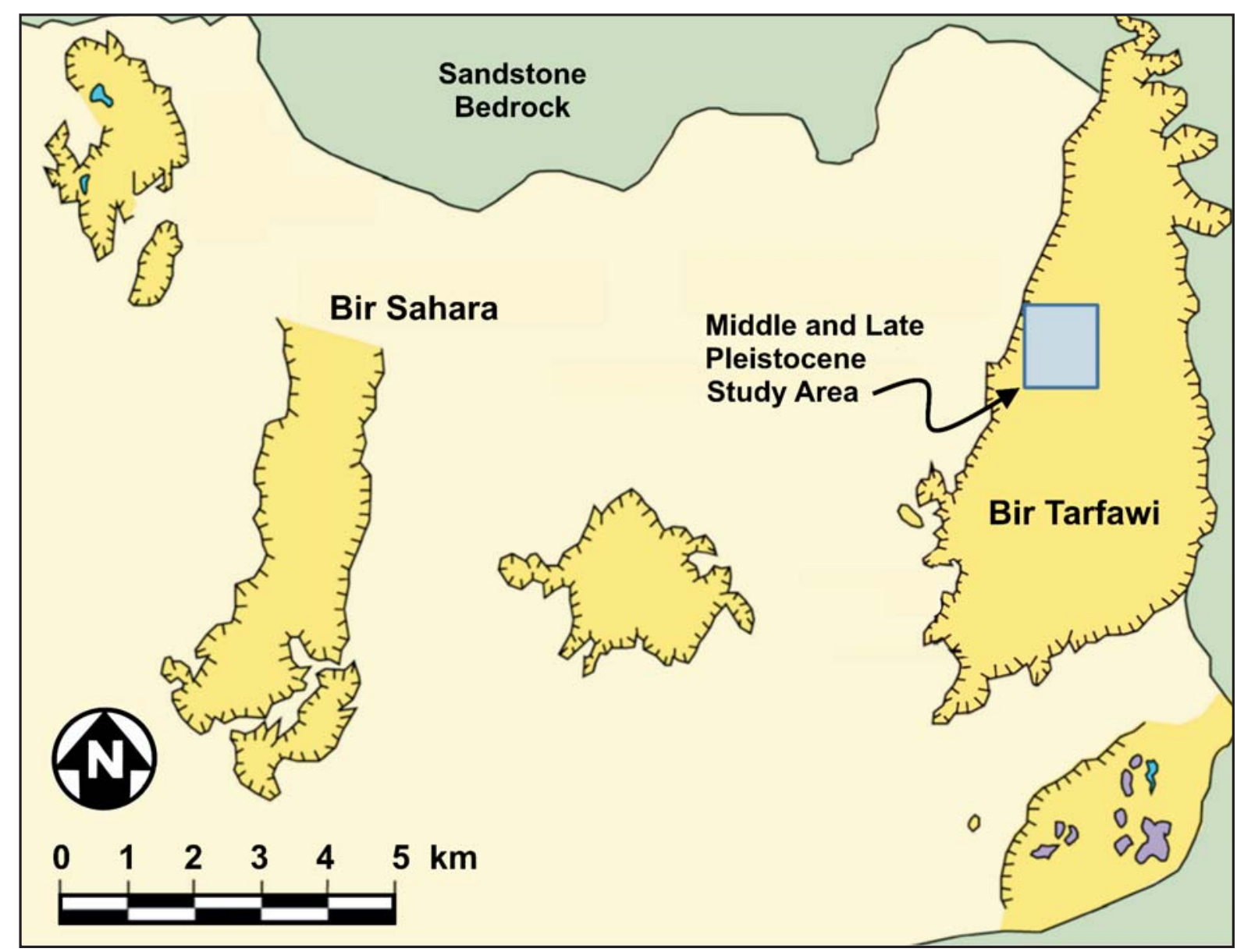

Fig. 3. The location of the study area (blue-gray rectangle) in the north-central part of the Bir Tarfawi erosional basin. The yellow areas are deflationary depressions that contain Middle and Late Pleistocene sediments. The most significant of these is the Bir Sahara area to the west of Bir Tarfawi.
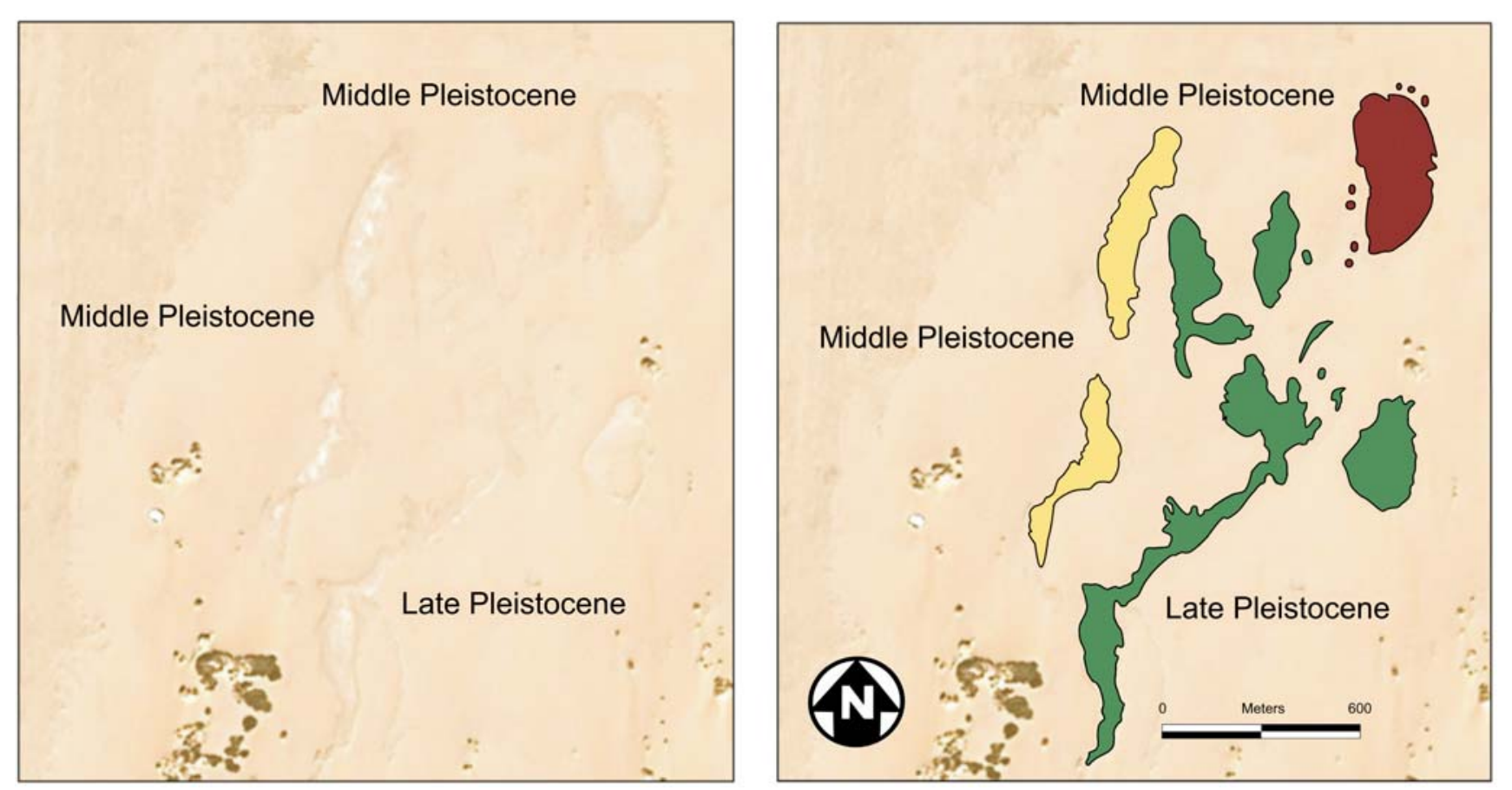

Fig. 4. Google Earth images of the study area showing the outlines and extent of the sedimentary remnants in the north-central part of Bir Tarfawi. The map on the left shows the original image (2006 Google image) while the map on the right highlights the Middle and Late Pleistocene sedimentary remnants. Colors indicate sedimentary remnants. Middle Pleistocene sediments associated with Acheulian artifacts are brown, Middle Pleistocene sediments associated with Middle Paleolithic artifacts are yellow-tan, and Late Pleistocene sediments with Middle Paleolithic artifacts are green (see Fig. 5) 


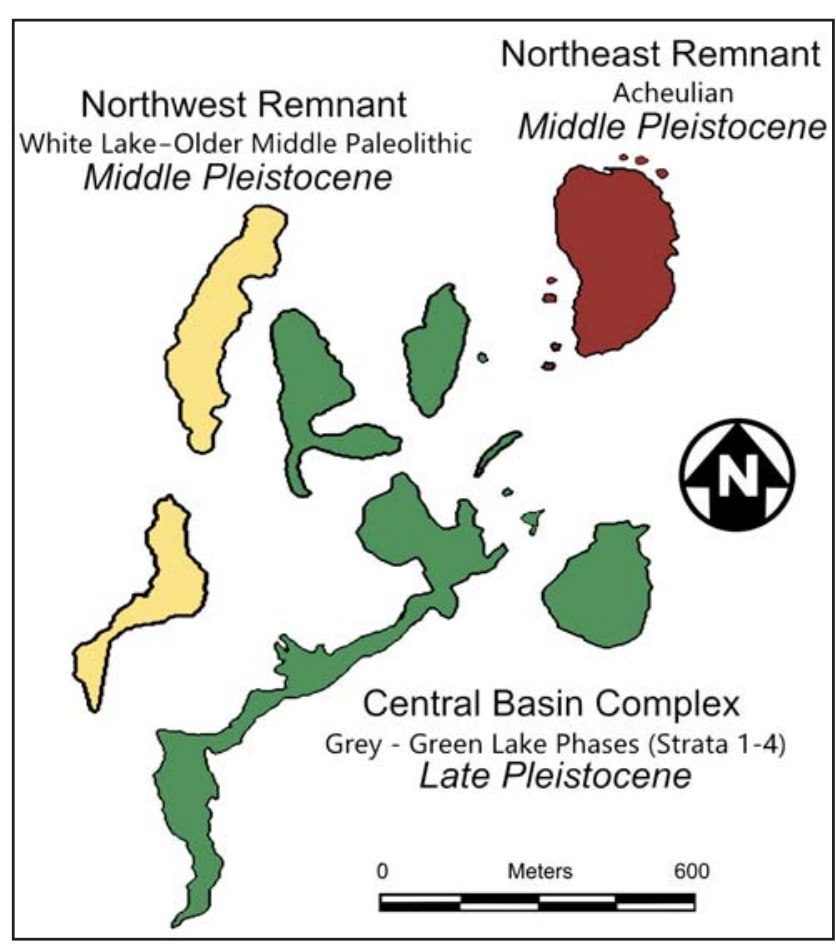

Fig. 5. The study area showing the major sedimentary remnants. The northeast remnant is associated with Acheulian artifacts (brown on map, see also Fig. 6 for details). The northwest ("White Lake”) remnant sequence contains Middle Paleolithic artifacts (yellow-tan on the map). The Central Basin deposits are associated with the grey-green basin fill sequence and contain Middle Paleolithic artifacts and fossils (green on the map).

for each sedimentary sequence are: thickness of unit (to the nearest cm using measuring tapes with metric scales), dominant color (based on dry Munsell color), coherence or cementation, bedding and structures, boundaries, as well as fossil and artifactual content. When primary sedimentary features were evident, the angle of dip, the presence of cross- or parallel-bedding, and the presence of graded sequences was noted. Truncations or erosional surfaces were also noted. Post-depositional features (such as liquefaction features and possible pedogenetic or bioturbation structures) were also documented. Dilute $\mathrm{HCl}$ acid was used to determine the presence of carbonate. Field descriptions of the stratigraphic sequences were supplemented by elevation data provided by topographic mapping by R. Schild and A. Mazhar and elevations provided by A. Ibrahim (a topographic map from this effort is published in Schild and Wendorf (1993)).

Laboratory analyses were conducted at the University of Minnesota's Archaeometery Laboratory (G. Rapp, Director) (Hill, 1992). Granulometric analyses of the sediments were used to document the textural properties of the sediments and compositional/geochemical analyses were conducted to measure the organic and carbonate content of the samples. The particle size analysis consisted of pretreatment to remove carbonates and organics, the use of a dispersal agent (sodium hexa-metaphosphate, to prevent flocculation of clay particles), wet sieving with a vacuum-aspirator, coarse fraction separation with a sonic sifter, and fine fraction separation using the pipette procedure. Then, samples were washed, dried, and weighed after pretreatment providing percent weight of carbonate and organic matter based on mass loss by chemical treatment (defined as total carbonate content or calcium carbonate equivalent). The gravel and various sand size fractions of the siliciclastic (detrital) component of each sample were measured using sieves. Losson-ignition was used to measure the organic matter or organic carbon content of the samples as well as the amount of calcium carbonate. X-ray diffraction was used to determine bulk mineralogy with calcium fluoride added as a marker. Other performed geochemical analyses included the measurement of stable isotopes (McKenzie, 1993a; McKenzie, 1993b; De Deckker and Williams, 1993; Bradbury and Hill, 2008) and chronometric dating (cf. Wendorf et al., 1994). Dating techniques included thermoluminescence (on sands) and uranium-series (on carbonates and cemented sands) measurements for the deposits associated with Acheulian artifacts (see below). Dating techniques for the sedimentary remnants associated with Middle Paleolithic artifacts included uranium-series measurements (on marls, carbonate, molluscs, tooth enamel, dentine, eggshell), electron spin resonance (on molluscs, tooth enamel, snail shells), optical luminescence (on sand), thermoluminescence (on burned quartzitic sandstone ("quartzite”), amino acid racemization (on eggshell) and radiocarbon (on organic residue, carbonaceous material, and molluscs (Melanoides)) (Wendorf et al., 1994).

\section{RESULTS}

\section{Northeast sedimentary section at Bir Tarfawi}

Within the larger deflational area of Bir Tarfawi, this sedimentary remnant (Figs 4-9) forms a low lying mesa-like landform with a surface elevation of about 247-249 m a.s.l. This is the highest stratigraphic sequence, with a surface at almost the same elevation as the edge of the surrounding plateau. The low limestone capped remnant is surrounded by small mounds composed of sandstones and mudstones (indurated, cemented clastics, Figs 6 and 7). Artifacts (including Acheulian hand axes and bifaces) are found scattered on the deflated surfaces surrounding the remnant and the associated spring vents, no artifacts were discovered in situ, within the sediments. The artifacts exhibited varying stages of weathering, implying different lengths of aerial exposure and indicating the objects were once embedded in deposits along the present edge of the remnant.

The deposits that are preserved appear to reflect sedimentation near the center of the basin; no near-shore facies are present, based on lithologic properties of the sediments and their stratigraphic context. Primary sedimentary structures such as bedding are not present; the deposits exhibit evidence of bioturbation and/or post-depositional processes. The upper section of the limestone is lithified (indurated) consisting of orthochemical sparite, and the surface exhibits large contraction desiccation polygons, suggesting that 


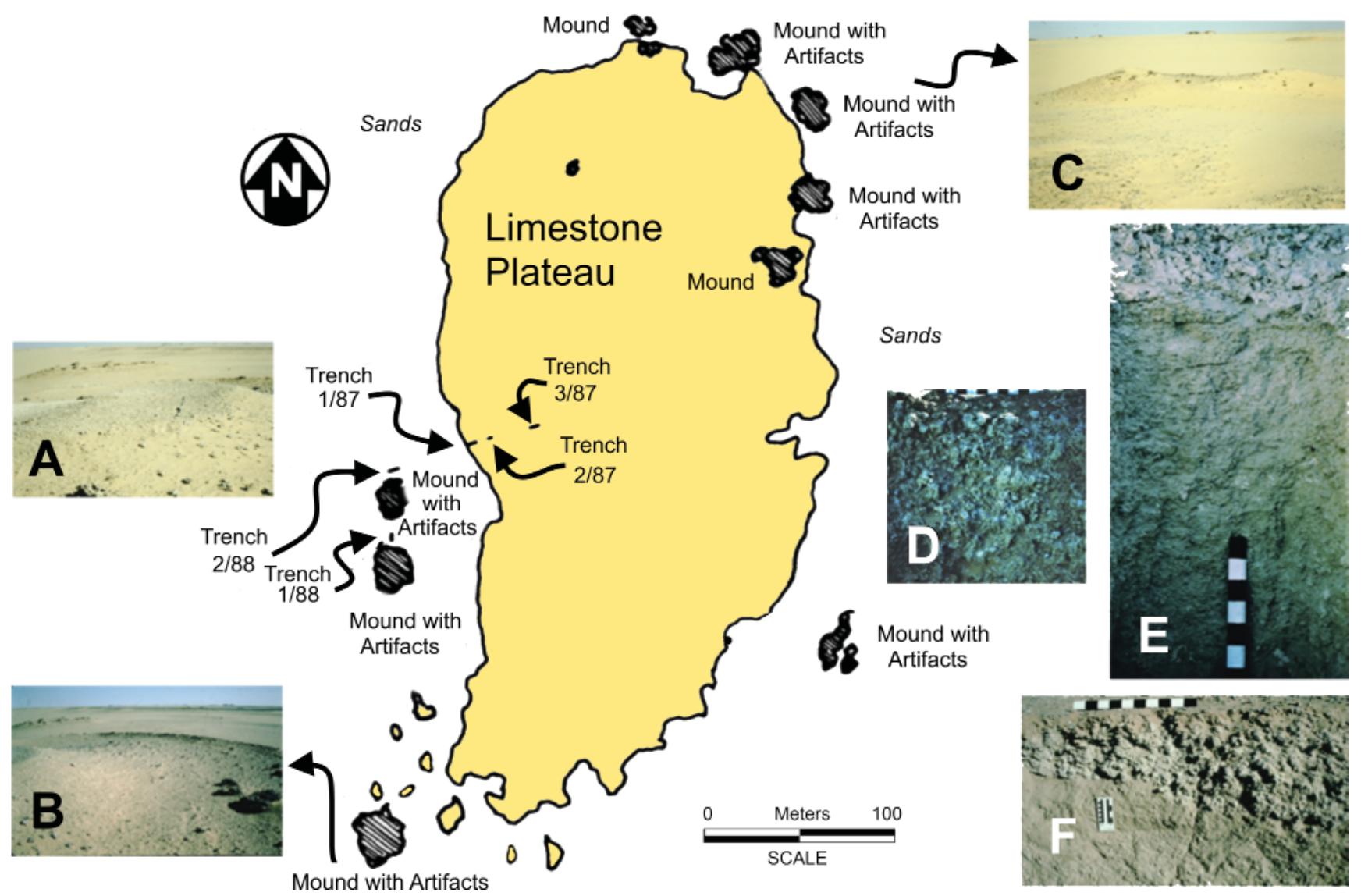

Fig. 6. Acheulian sedimentary remnant (northeast remnant in study area). A-C are images of spring vent remnants with Acheulian artifact scatters. D-F are images of sedimentary deposits from the stratigraphic trench excavations. The remnants and trenches associated with A (Trench $1 / 88$ and 2/88) are shown in detail on Fig. 7. Fig. 8 provides details for Trench 3/87 and Fig. 9 provides the details for 1/87 (see images D-F).
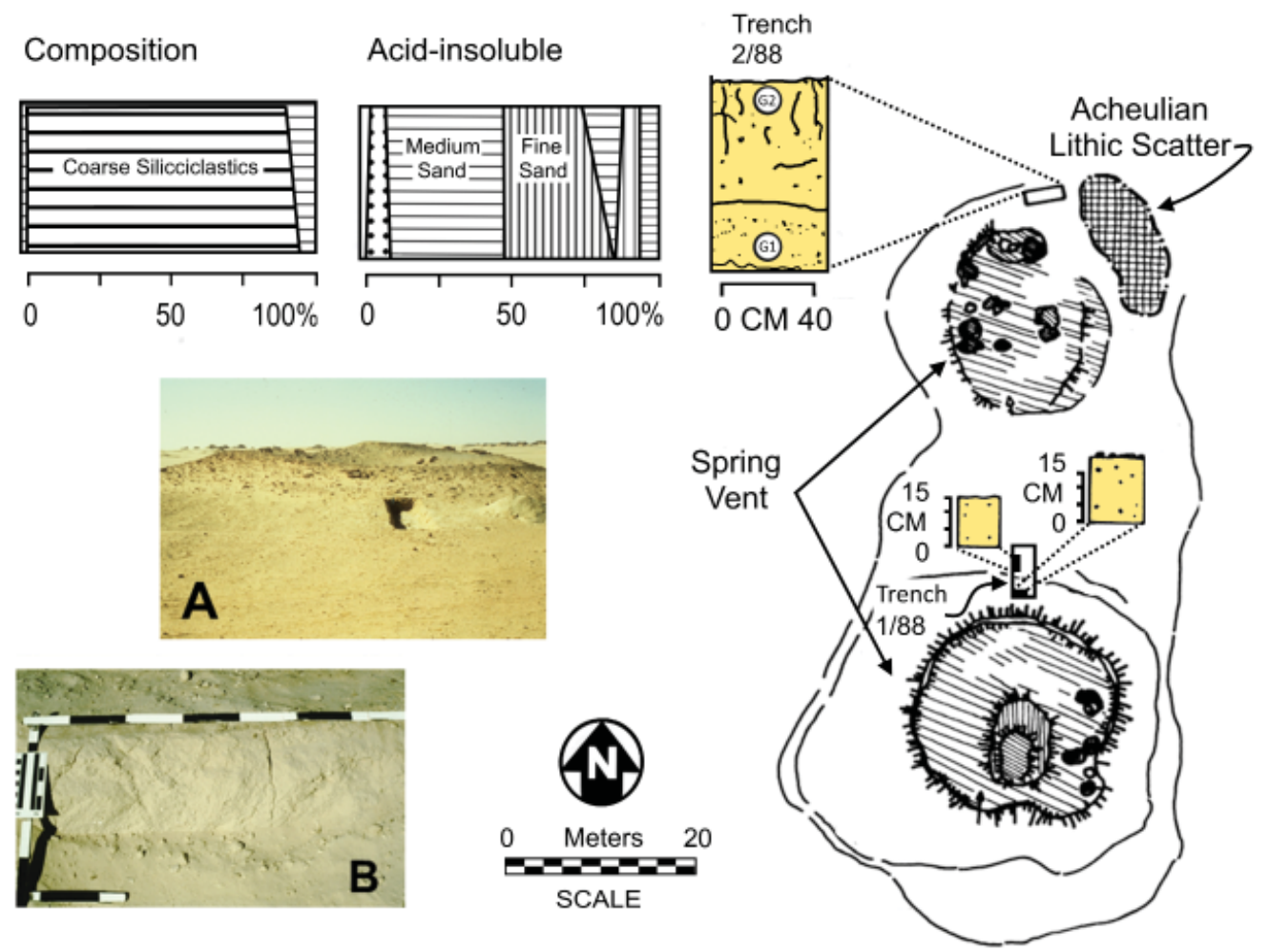

Fig. 7. Detailed map of west side of Acheulian remnant (see Fig. 6A) and locations of stratigraphic trenches 1/88 and 2/88 related to spring vent sediments. A: photograph of Acheulian spring vent and the excavations at Trench 1/88. B: sand deposits at Trench 1/88. Compositional information is provided for geology samples 1 and 2 (G1 and G2) collected from sediments at Trench 2/88. 
there has been no significant erosion of the stratigraphic sequence associated with the depositional cycle.

The sequence consists of coarse siliciclastics (chiefly medium and fine sands) overlain by deposits high in carbonate and a siliciclastic (detrital) fraction containing higher amounts of silt and clay (Hill, 2001). Sediments high in carbonate are present at Trench $3 / 87$ closer to the center of the remnant (Figs 6 and 8). Based on the application of Walther's Law for stratigraphic sequences, the sedimentary deposits high in carbonate are interpreted as a deeper water lithofacies, and are considered to reflect a transgressive, high water phase for the water body within this deflational basin. The low amounts of clastics present in the sediments containing high amounts of carbonate (possibly deposited at the peak of the wet climate cycle) suggest that the surrounding region was covered by vegetation. Vegetation would have potentially reduced the erosion, transport and deposition of sands into the basin. Closer to the edge of the remnant, at Trench 1/87 (Figs 6 and 9), carbonates with silts are overlain by sediments dominated by clastics, suggesting the initiation of a regressional depositional event with a reduction in the size of waterbody at the close of a wet climate cycle.

The preserved central, deeper water facies is about 400 X $200 \mathrm{~m}$ and implies the presence of a relatively small spring-fed lake or pond and possibly marsh conditions, with spring deposition in the now deflated near shore areas. Uranium-series measurements on a sample of carbonate and a sample of calcareous sand have been used to speculate that this remnant is perhaps older than $400 \mathrm{ka}$ (400$600 \mathrm{ka}$, Schwarcz and Morawska, 1993, samples 87BTF 17 and 19). Based on the presence of Acheulian artifacts this sequence would be assigned to the Abbassian (Said, 1990; Hill, 2002). The base of the lake (the boundary between older sands and gravels and carbonate deposits, at Trench $3 / 87$ in the central part of this remnant) indicates the waterbody filled an erosional basin starting at an elevation at about $247 \mathrm{~m}$ a.s.l; the surface elevation of the sediments indicates the water levels were at least above $249 \mathrm{~m}$ a.s.l. during the maximum wet stage.

\section{Northwest sedimentary section at BirTarfawi}

About $600 \mathrm{~m}$ to the southwest of the remnant associated with Acheulian artifacts is an elongated, $100 \times 500 \mathrm{~m}$, low lying mesa-like landform with a surface elevation of 246 $\mathrm{m}$ a.s.l., designated as the "White Lake" (Figs 5, 10 and 11). Artifacts assigned to the Middle Paleolithic (mode 3, Levallois) (represented by the E-88-14 artifact assemblage) are embedded in deposits of this remnant; the artifacts are concentrated along the southwest edge of the remnant. While the foreshores and beach zones of this basin have been removed by erosion, shallow-water and deeper-water sedimentary lithofacies are preserved.

The lower part of the sedimentary sequence consists of clastic deposits (sands) exhibiting extensive iron and manganese staining, interpreted as a hydrogenic-hydromorphic

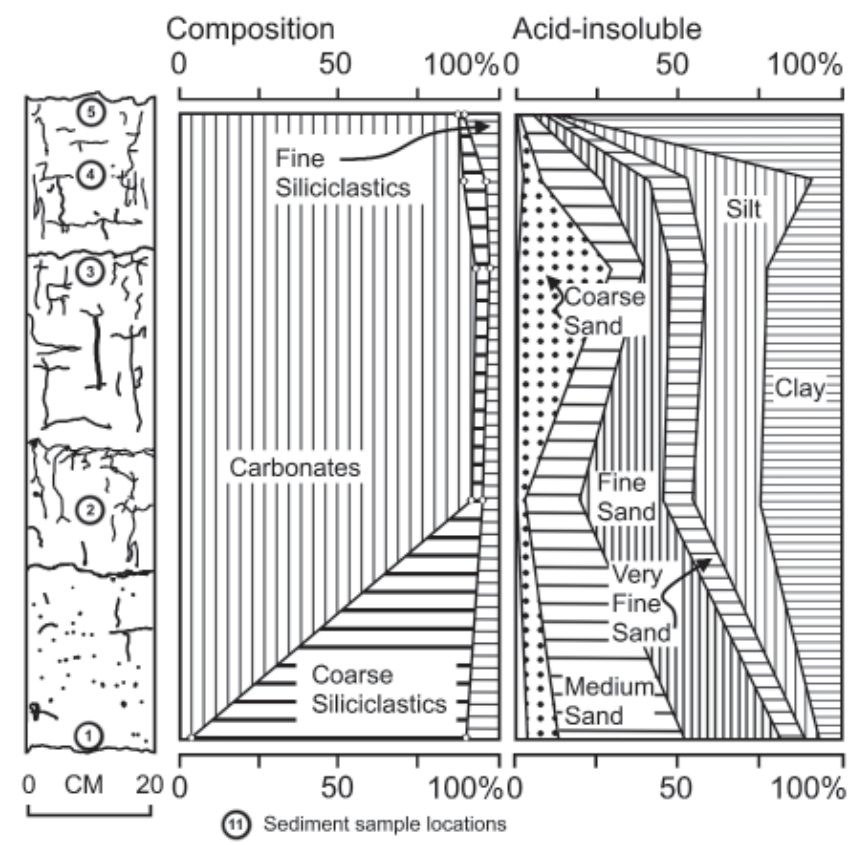

Fig. 8. Sedimentology and stratigraphy of Trench $3 / 87$ (T.3/87) located near the central part of the Acheulian remnant (see Fig. 6 for location of trench). Circles on stratigraphic profile indicate location of sediment samples. The sequence is dominated by carbonates deposited within a Middle Pleistocene basin.

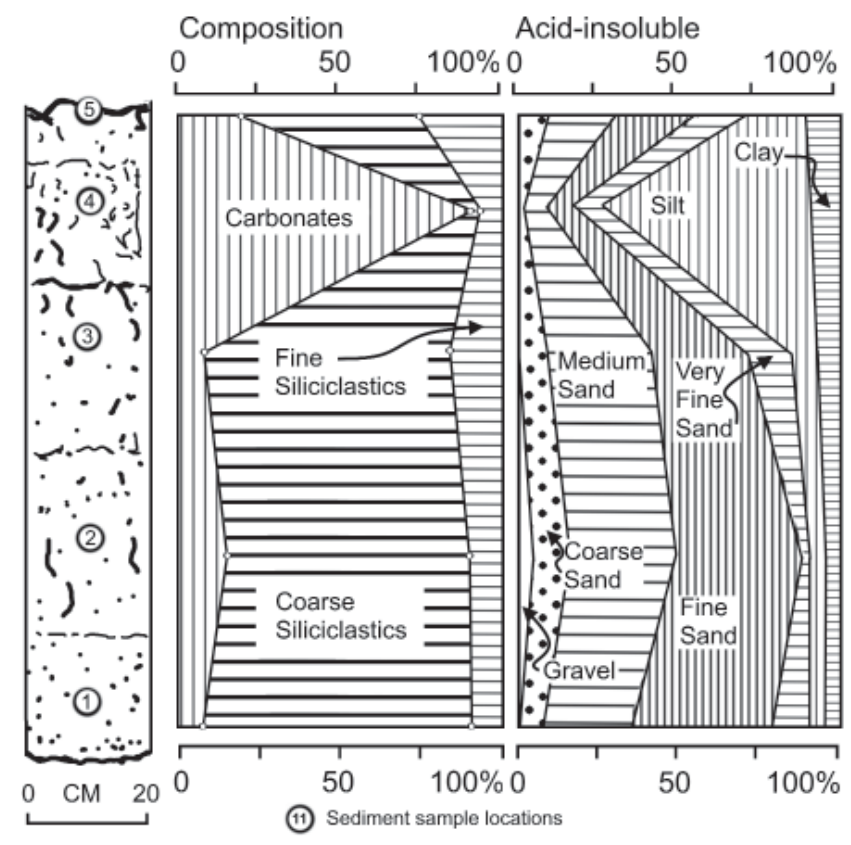

Fig. 9. Sedimentology and stratigraphy of Trench 1/87 (T.1/87) located closer to the edge of the Acheulian remnant (see Fig. 6 for location of trench). Circles on stratigraphic profile indicate location of sediment samples.

inceptisol (aquept) (Fig. 11). This is overlain in the central part of the remnant by about $2 \mathrm{~m}$ of carbonate deposits, with some sections containing molluscs. The shallow water facies (Trench 10/86, Fig. 10) contains a coquina with Bulinus, Melanoides, and Lymnea in deposits above the inceptisol. An erosional boundary separates the coquina from sandy marl containing some Melanoides (Fig. 11). Another erosional surface separates the sandy marl from 


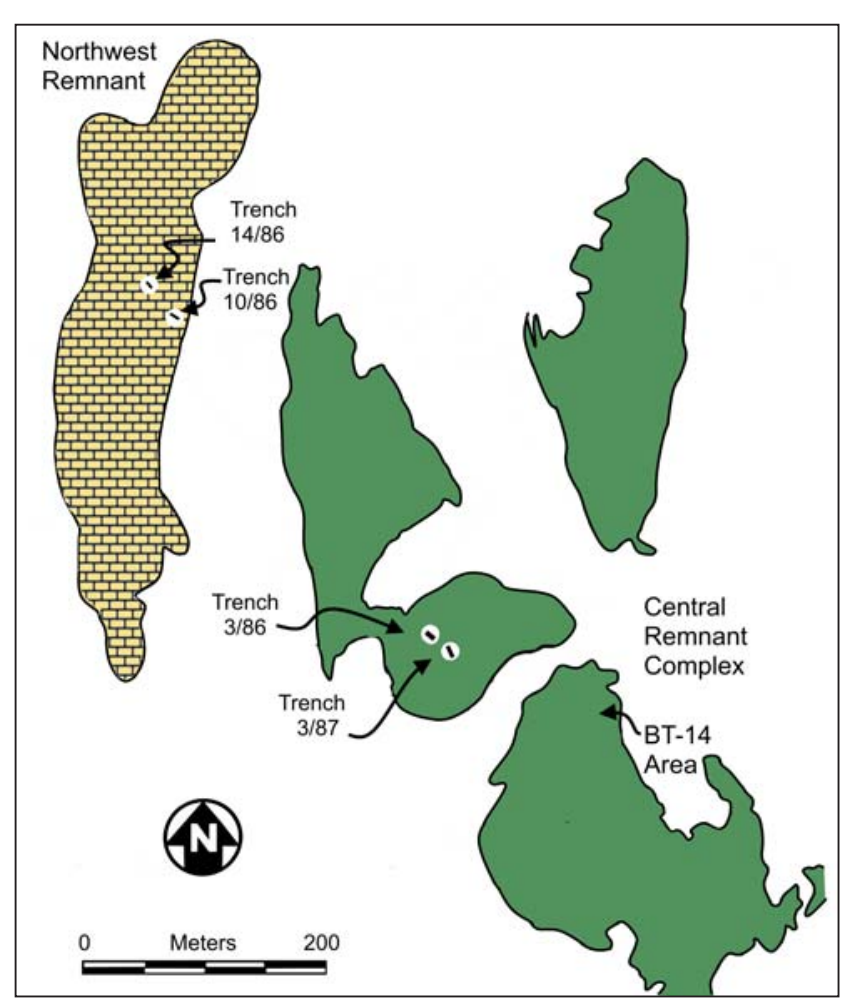

Fig. 10. Map of northwest remnant and Central Basin sedimentary complex showing locations of trenches described in the text. Trench 10/86 (T.10/86) and Trench 14/86 (T.14/86) are on the northwest remnant (see Fig. 11 for stratigraphy), shown in yellow. The BT-14 (Bir Tarfawi Site 14) area within the Central Basin is shown in detail on the Fig. 12 map. Trench 3/86 (T.3/86) and Trench 3/87 (T.3/87) are also part of the Central Basin (see also Fig. 17); the Central Basin surface sediments are green on this map.

laminated marl that is covered silts by lithified plates of a sandy limestone.

The initial base of the waterbody, as indicated by the boundary between older sands and gravels and sediments deposited within the basin, is at about $244.4 \mathrm{~m}$ a.s.l. This indicates that the local surface was deflated about $2.5 \mathrm{~m}$ below the base of the Acheulian remnant. A rising water-table may have led to sediment deposition in a relatively small confined basin, as indicated by the carbonates. The low amount of clastics associated with the carbonates is consistent with the possibility that vegetation in the area surrounding the waterbody reduced clastic influx. In Trench 10/86 near the edge of the remnant the clastic (detrital) fraction is higher (sample 3, Fig. 11) and this is interpreted as reflecting a reduction in the size of the volume of the waterbody, and the onset of drier conditions that would have reduced vegetation cover in the surrounding landscape.

Two hydrologic patterns appear to be superimposed on the stratigraphic record: first, a longer term cycle associated with a major wet "pluvial" event, and, second, possible seasonal fluctuations in the size of the waterbody. The carbonate mineralogy for the marl sequence at Trench $14 / 86$, as reflected in low $\mathrm{Mg} / \mathrm{Ca}$ ratios ranging from 0-2.4 indicates these sediments were deposited in relatively fresh or sometime brackish water (McKenzie, 1993a, 1993b). The oxygen isotope values from this sequence have been inter- preted as indicating an evolving water body (McKenzie, 1993a, 1993b). For instance, McKenzie (1993a) documents a lower section with very negative values associated with the early stage of a wet climate event. The upper section also has very negative values and is interpreted as reflecting the later stages of a wet event. Ostracods collected from the near-shore facies deposits at Trench 10/86 are consistent with a fresh to slightly saline shallow water (De Deckker and Williams, 1993). Uranium-series measurements on four samples of marls from Trench 14/86 and a marl/molluscs sample from Trench 10/86 suggest the possibility that these deposits are late Middle Pleistocene in age (Schwarcz and Morawska, 1993, samples 87BTF-21, -32; McKinney, 1993, sample 40M1; Szabo et al., 1995, sample 25, 73Eg86). The measurement with the smallest standard deviation suggests an age of around 160 ka (Wendorf et al., 1994) while other ages are greater than $200 \mathrm{ka}$.

\section{Central Basin remnant complex at Bir Tarfawi}

Between the two likely Middle Pleistocene landforms that are associated with either Acheulian or Middle Paleolithic artifacts is an extensively studied complex of sediments associated with several Middle Paleolithic assemblages, notably BT-14 (Bir Tarfawi Site 14) and site E-87-5 (Figs 5 and 12). The sediments in this central area fill what was a topographic low. It is a deflational basin indicating an interval of erosion and a lowering of the groundwater level to at least ca. $242 \mathrm{~m}$ a.s.l. (at Trench 8/74). This documents a drop in the water table that was about $5 \mathrm{~m}$ lower than the documented deflation prior to the Acheulian age sequence and about $2 \mathrm{~m}$ deeper than the northeast "White Lake" remnant basin erosional surface. There are several sub-basins associated with this sedimentary sequence and it is possible to also distinguish several lake phases within the sedimentary sequence. In this paper we focus primarily on the lithostratigraphic evidence that can be used to distinguish horizontal and vertical lithofacies variation within the Central Basin.

Figure 13 is a composite section across part of the Central Basin remnant, showing the broad stratigraphic relationships between 4 trenches associated with the major archaeological excavations at BT-14 (Fig. 12 shows the location of these trenches and the BT-14 excavations, Fig. 14 shows the location of samples collected from the archaeological excavations at BT-14, Fig. 15 shows the location of samples collected from Trench 14/74, and Fig. 16 shows the samples locations for Trench 16/74). In this composite section the lowest deflational surface formed prior to the deposition of basin-fill lake-related sediments is at $242.2 \mathrm{~m}$ a.s.l. at the Site BT-14 excavations. The horizontal sequence consists of 4 major strata (the grey-green lake phases in Schild and Wendorf, 1993). Deposits assigned to stratum 1 (grey phase 1) were documented in Trenches 16/74 and 1/87 as well as the Site BT-14 excavations. Strata 2-4 (grey phases 2 and 3, green phase) are present at all these locations and at Trench 14/74. 

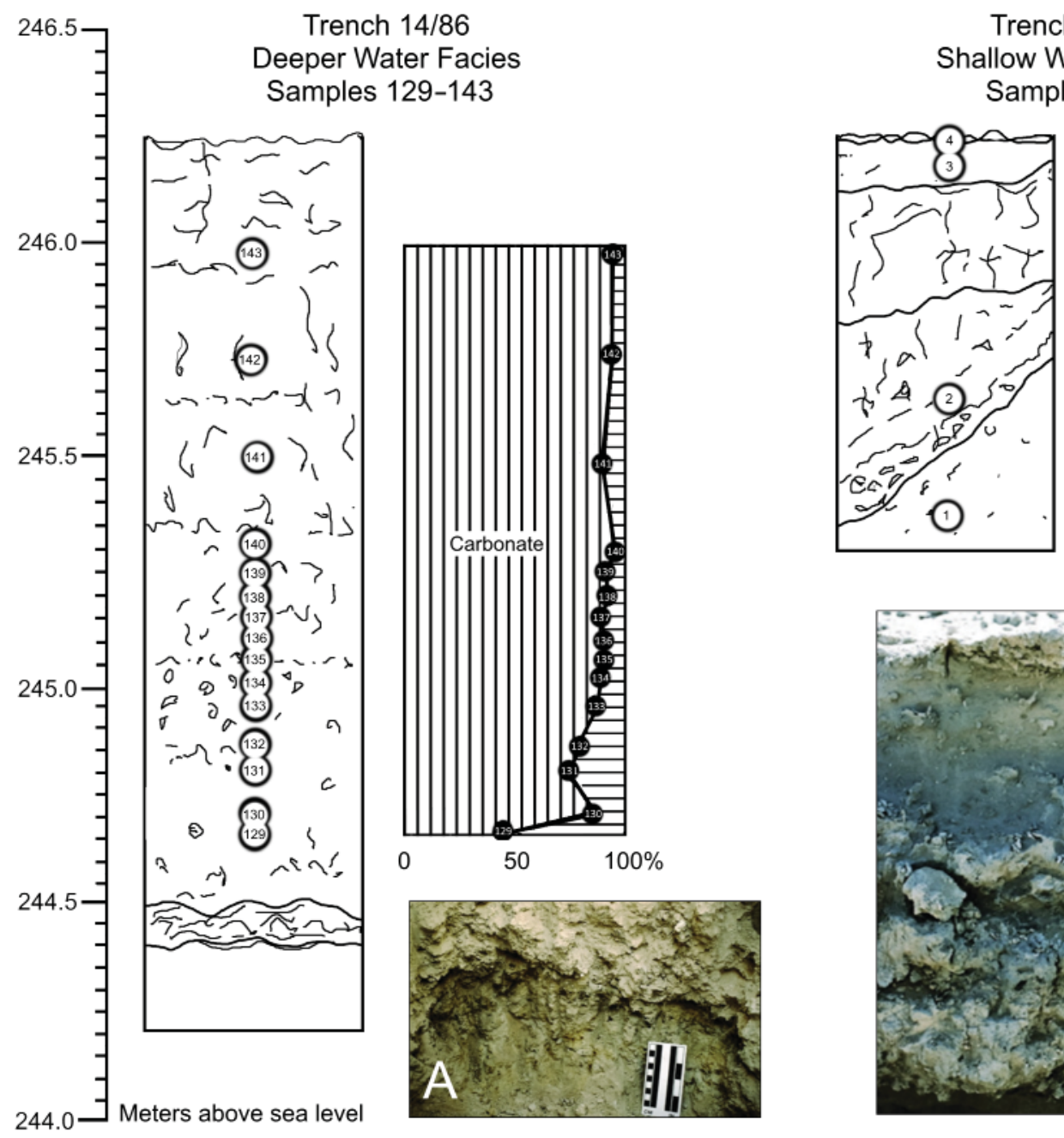

Trench 10/86

Shallow Water Facies

Samples 1-4
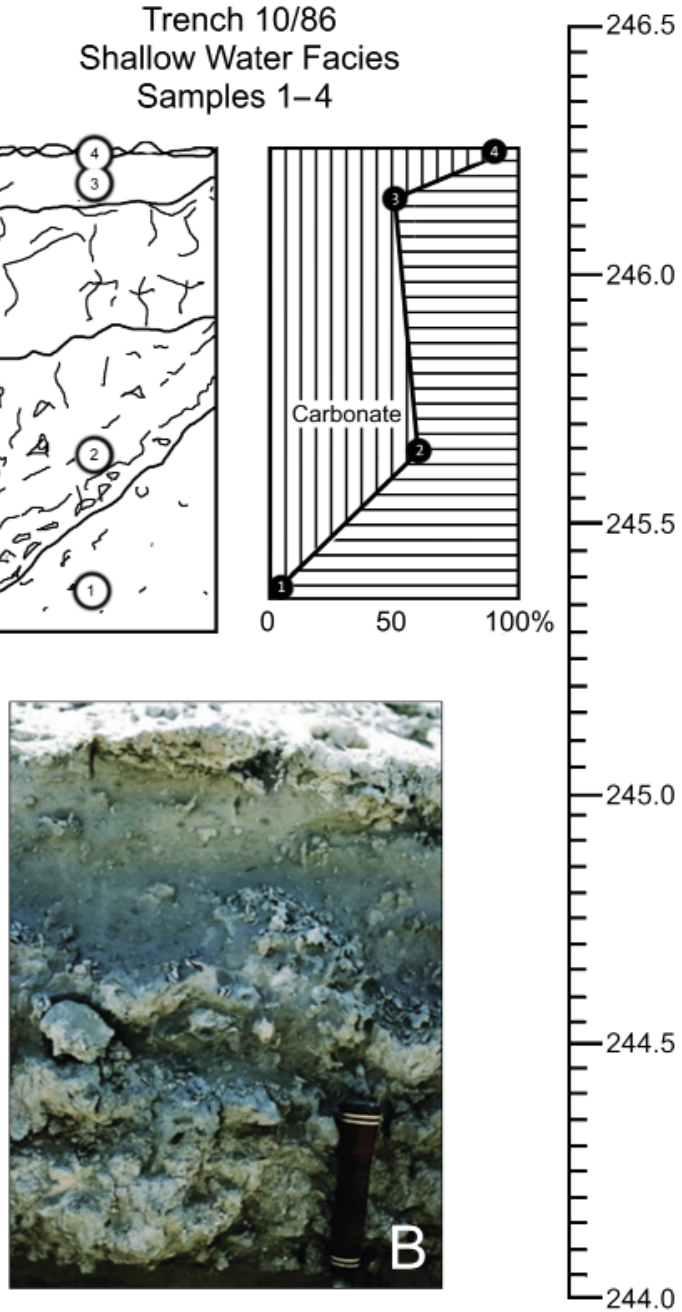

Fig. 11. Sedimentology and stratigraphy of the northwest ("White Lake”) remnant. Trench 14/86 is near the central part of the remnant while Trench $10 / 86$ is about $50 \mathrm{~m}$ away at the edge of the remnant (see Fig. 10). A: basal deposits at Trench 14/86. B: Stratigraphic sequence of sediments at Trench 10/86. The circles on the stratigraphic sections show the location of sediment samples collected for analyses.

The sedimentological (textural and compositional) characteristics along the north wall of the BT-14 excavations are shown in Fig. 14. Stratum 1 overlies an erosional surface and is dominated by coarse siliciclastics (quartz sands). Laminae dip towards the center of the basin (westward) at angles from $5-15^{\circ}$. The unit contains molluscs, bones, and artifacts as well as light gray (10YR 7/1-2) pebbles of cemented carbonate mud. The upper section of the unit has slightly higher carbonate content and is poorly sorted muddy sand. An erosional unconformity separates the top of stratum 1 from the deposits of stratum 2. Stratum 2 deposits at this location also are dominated by clastics, including slightly gravelly muddy sands with laminations that are horizontal or dip $5-15^{\circ}$ to the west. An erosional unconformity separates stratum 2 and the deposits of stratum 3. The lower section consists chiefly of sands; silts and carbonates are higher in the upper deposits of this stratum (muddy sand, sample 22, Fig. 14). The lower deposit of stratum 4 (the green lake phase) is a muddy sand with low amounts of carbonate while the top bed has more mud and more carbonate. The sequence at BT-14 is interpreted as indicating episodic filling of the deflational basin. A general fining upward of mean grain size and sorting may indicate that the water bodies were progressively larger.

East of the BT-14 excavations (Fig. 12), the sedimentary sequence at Trench 16/74 (Fig. 16) appears to reflect four transgressive episodes primarily associated with the redeposition of clastics within the paleo-basin. West of BT-14 at Trench 14/74 the sedimentary sequence illustrates the nature of clastic and chemical deposition nearer the center of the basin. Sedimentological data from these trenches associated with BT-14 indicates that the sediments reflect lateral depositional facies within the basin (Figs 15-16). For example, sediments from Trench 16/74 contain lower amounts of carbonates while, in contrast, the sediments associated with strata 2-4 at Trench 14/74 have much lower amounts of coarse clastics and are composed of high amounts of finer clastics and carbonates or are almost exclusively composed of carbonates. This pattern of lateral variation is interpreted as reflecting near shore (Trench 16/74) and deeper water (Trench 14/74, Fig. 15) depositional facies with the Central Basin complex. If this is the case, these lithofacies variations should provide an indication of the size and extent of the water body at the times when the sediments were deposited. 


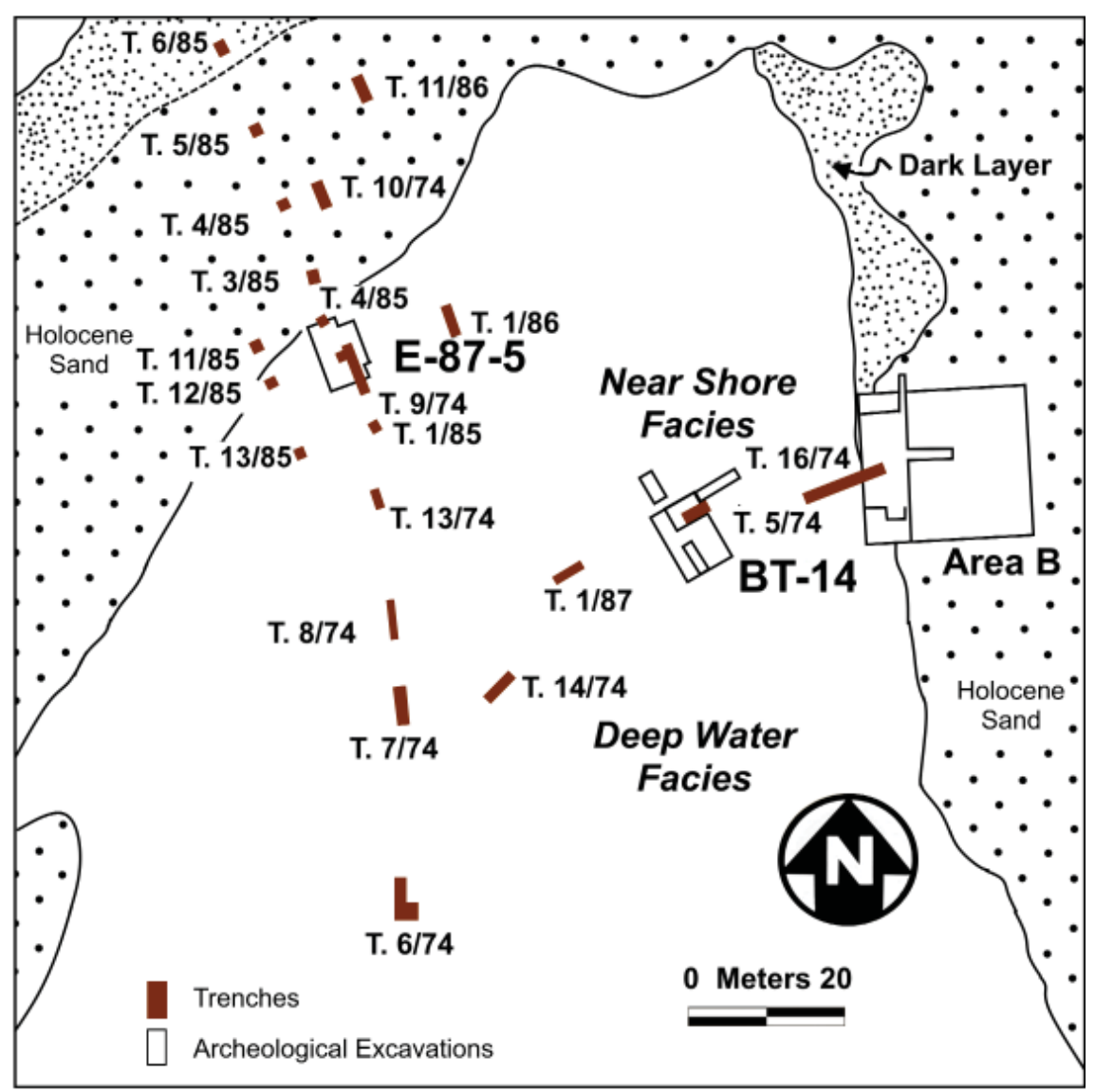

Fig. 12. Map showing location of stratigraphic trenches in area around the BT-14 (Bir Tarfawi Site 14) excavations. Trenches (= T) are labeled according to the order they were first excavated (thus, T. 1/87 indicates the location of the first trench excavated in 1987 in this area). Note locations of Trench 16/74 (T. 16/74) at edge of remnant associated with the near shore sedimentary facies and Trench 14/74 (T.14/74) in the central area of the basin associated with the deeper water facies (see Fig. 13 for composite cross-section). The label BT-14 designates the location of Bir Tarfawi Site 14 archaeological (Middle Paleolithic) excavations (Area B is the location studied in 1974). The 1986/1987 excavations at BT-14 expanded in the area of Trench 5/74 (T. 5/74), between T. 16/74 and T. 1.87. E-87-5 is the location of additional Middle Paleolithic archaeological excavations in the area.

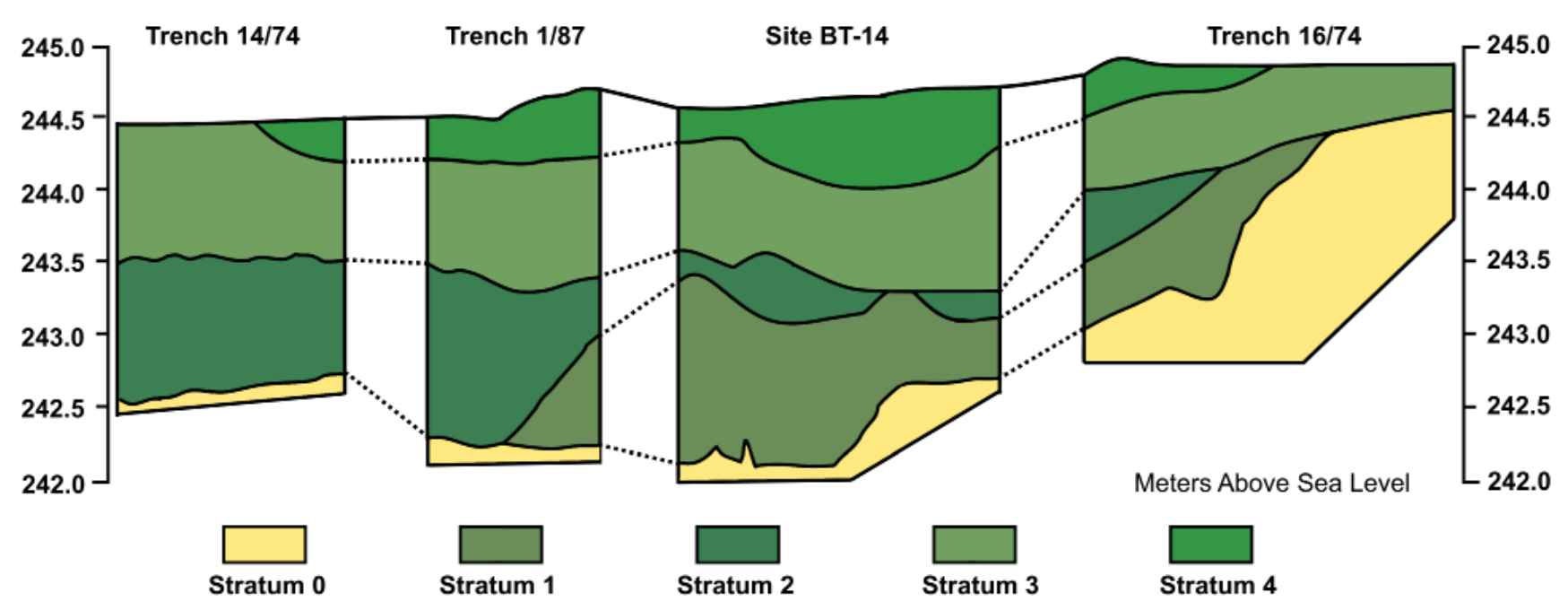

Fig. 13. Generalized composite cross-section showing trench locations and correlations of strata in Bir Tarfawi Site 14 (BT-14) area. Trench 14/74 is situated near the middle of this sedimentary remnant while Trench 16/74 is situated closer to the edge of the depositional basin (see Fig. 14 for BT-14, Fig. 15 for Trench 14/74, and Fig. 16 for Trench 16/74 stratigraphy and sedimentology).

Besides the clear pattern in horizontal (lateral) facies spatial variation, the sequences also illustrate textural (clastic size fraction) and compositional (siliciclastic vs. carbonate content) variability that reflects changing depositional environments over time within the basin, even though episodes of deflation have perhaps removed or eroded some sediments deposited in the later stages of each major depositional phase. Relative differences in the carbonate-clastic 


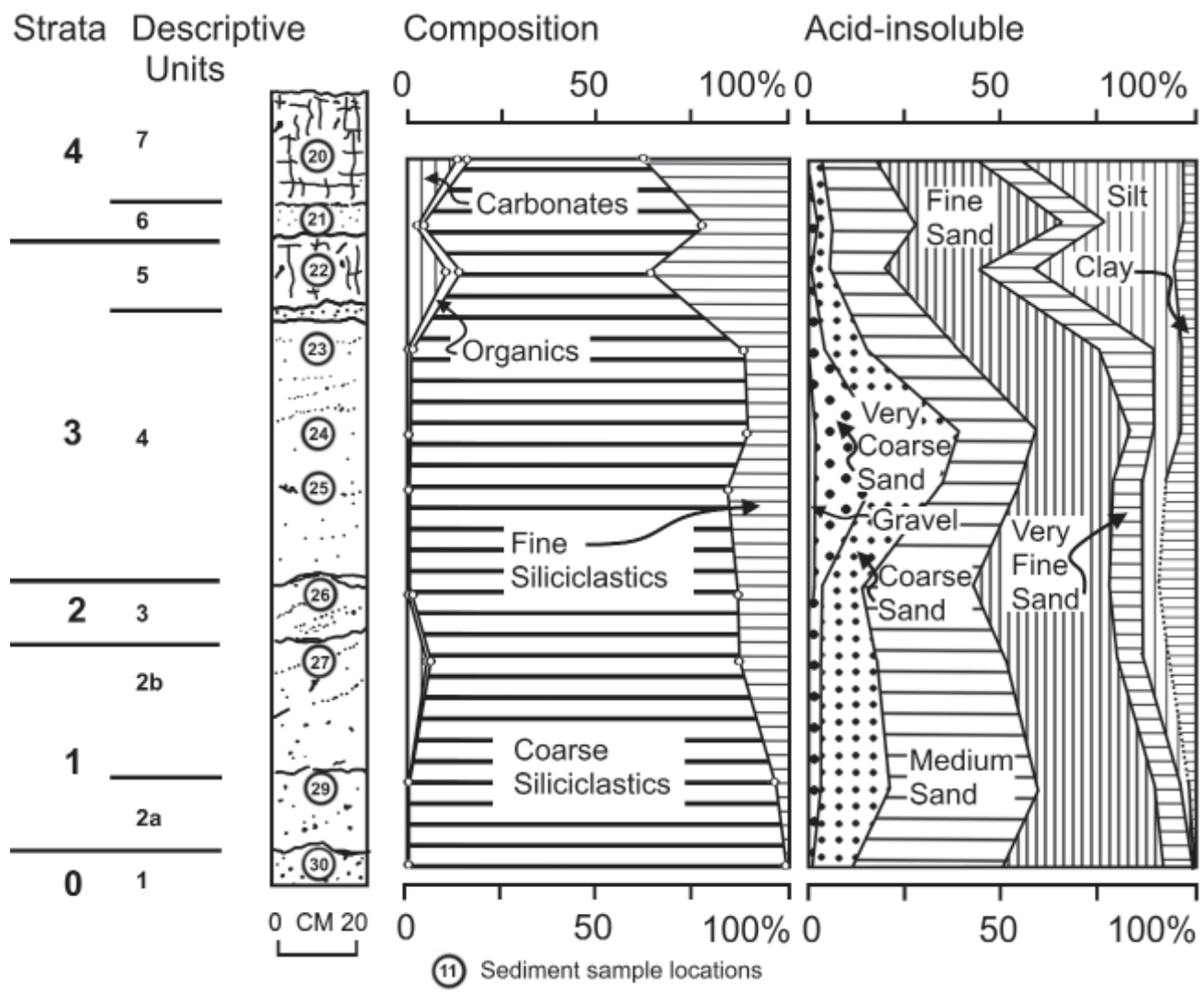

Fig. 14. Sedimentology and stratigraphy of deposits at BT-14 (Bir Tarfawi Site 14). Numbers in circles are sediment sample locations.

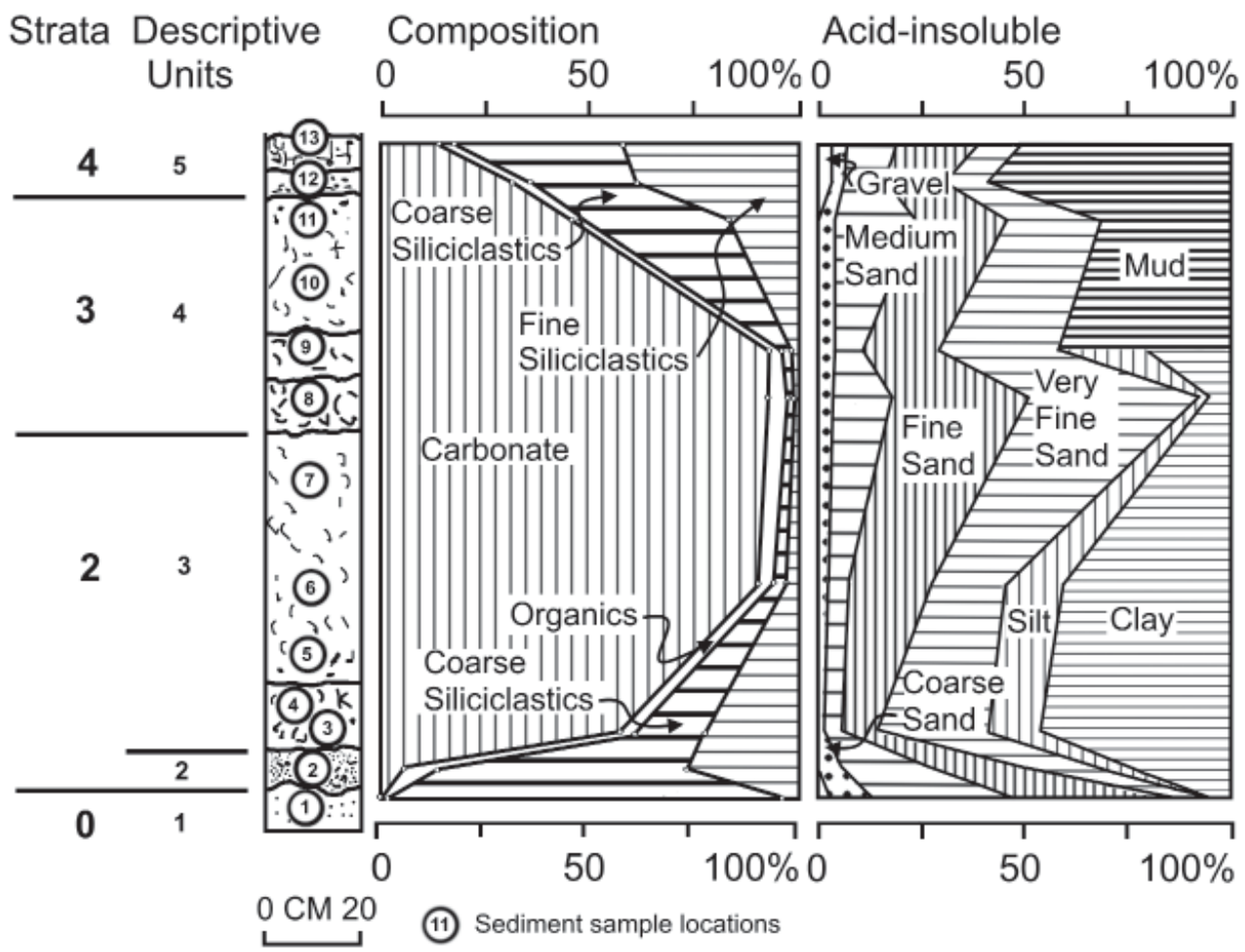

Fig. 15. Sedimentology and stratigraphy at Trench 14/74 (T. 14/74) in the general area of BT-14. Numbers in circles are sediment sample locations. The high amounts of carbonate and mud (fine siliciclastics) are indicative of deposition in the central, deeper water, area of the sedimentary basin.

ratios should reflect changes to the size and depth of the water body. In the near shore area, for example, carbonate content is higher within stratum 2 (grey lake phase 2) and stratum 4 (green lake phase) when compared to the shore deposits associated with stratum 3 (grey lake phase 3); this may be an indication that strata 2 and 4 reflect a larger 


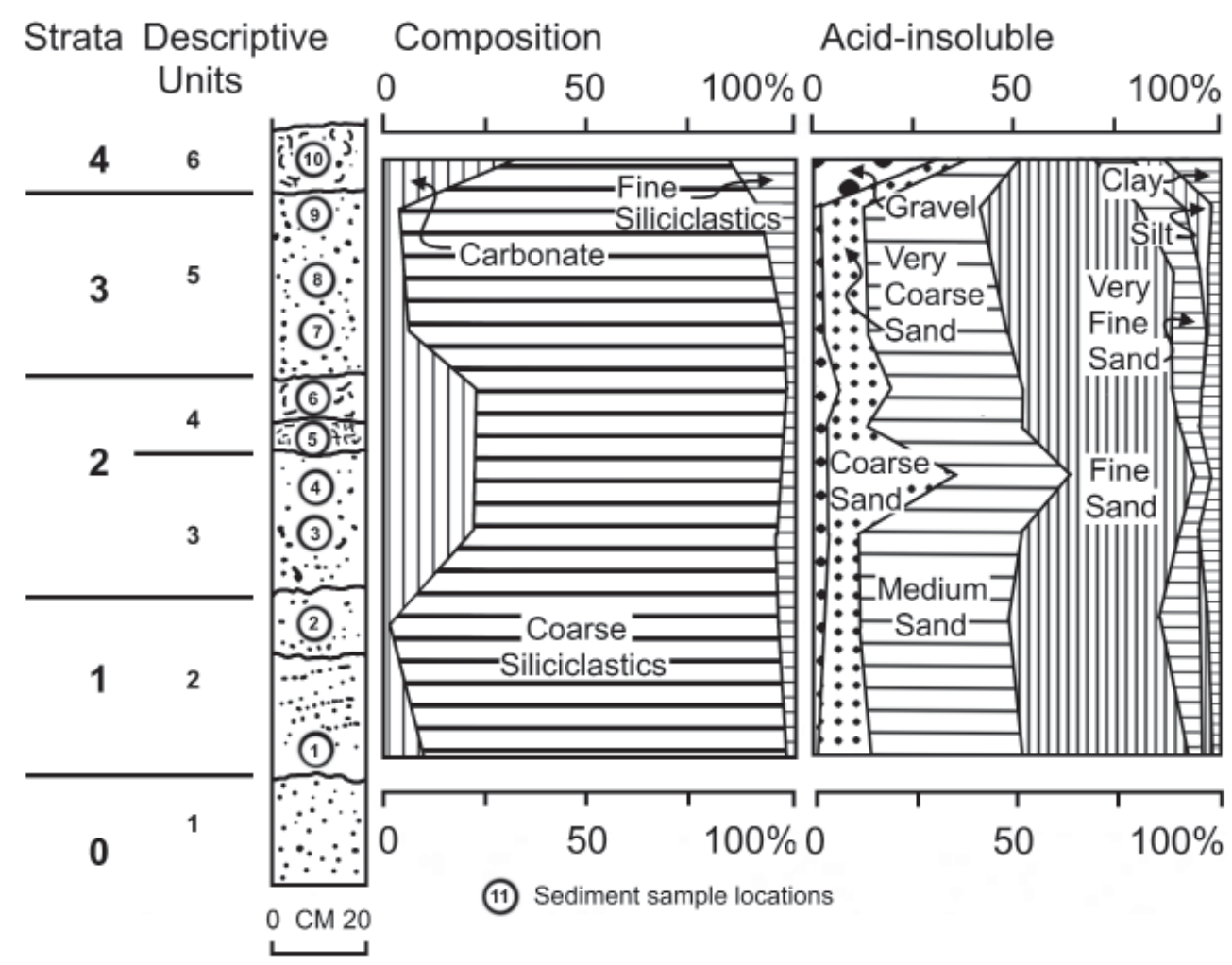

Fig. 16. Sedimentology and stratigraphy of Trench 16/74 (T.16/74). Numbers in circles are sediment sample locations. The high amounts of sand (coarse siliciclastics) are indicative of deposition in the near shore area, or edge of the sedimentary basin.

waterbody compared to stratum 3. In the deep part of the basin, stratum 2 shows a steady increase in carbonates at the expense of clastics, while strata 3 and 4 show a decrease in carbonate content over time. A pulse of mud deposition (sample 12, Trench 14/74, Fig. 15) may correlate with a transgressive phase within stratum 4 (green lake phase). To summarize, the textural and compositional variation observed within the stratigraphic sequence associated with the Central Basin remnant complex appears to provide an indication of the changes in the spatial extent of the waterbody within the deflational basin. The variation in facies can be interpreted as reflecting the presence of a waterbody that did not extend outside the present Bir Tarfawi depression and expand onto the surrounding higher plateau.

Along with Middle Paleolithic (Levallois, mode 3) artifacts, vertebrate and invertebrate fossils have been recovered within the sedimentary sequence of the Central Basin. The most common forms of vertebrates are gazelles, along with-as examples-rhinoceros, equid (wild ass), warthog, giraffe and buffalo (Gautier, 1993). Smaller mammals include hare, porcupine, wild cat, jackal, and hyena. Based on the types of large and small vertebrates, local rainfall estimates of 400-500 mm have been proposed (Gautier 1993; Kowalski et al., 1989). Fish bones recovered from these deposits provide some information on hydrologic conditions (Fig. 17). Clarias are fish that can live in small muddy pools, and tilapia are able to live in larger water bodies, while the presence of Nile perch (Lates niloticus) appears to indicate the waterbody associated with stratum 2 (grey phase 2) was at least $3 \mathrm{~m}$ deep. The artifacts and bones distributed within sands of stratum 1 (grey phase 1) suggest seasonal variation in the size of waterbody, to the extent that during the dry season the waterbody would have been reduced to a very small pool. Judging from the lithostratigraphic evidence (carbonate content, fine clastics) stratum 2 may represent the wettest interval within the Central Basin complex, while stratum 3 deposits suggest the waterbody was smaller than before. Stratum 4 (green lake phase), based on carbonate content and fine clastics, may reflect a seasonal water body within a shallow, large basin.

The oxygen isotope composition of carbonates (sedimentary matrix and molluscs) has been used to infer hydrologic changes, such as different phases of lake evolution. For example, Abell and Hoelzmann (2000) used isotope ratios of molluscs and bulk carbonate as proxies for precipitation and post-precipitational evaporation. Stable isotope studies from Bir Tarfawi may reflect post-precipitation fractionation due to evaporation (McKenzie, 1993a, 1993b; Bradbury and Hill, 2008; Fig. 17). A variety of chronometric techniques have been applied to samples collected from the Central Basin sequence including uranium-series, electron spin resonance, luminescence, racemization, and radiocarbon (cf. Wendorf et al., 1994). Large standard deviations make it difficult to be too confident about the use of some of these determinations. However, there are three TIMS uranium-series ages ranging from 137-122 ka with a standard deviation of $3 \mathrm{ka}$ as well as an age determination on tooth dentine of $85 \mathrm{ka}$ with a standard deviation of $2 \mathrm{ka}$ for the lowermost grey lake phase (stratum 1). Overall the deposits associated with the Central Basin sequence 

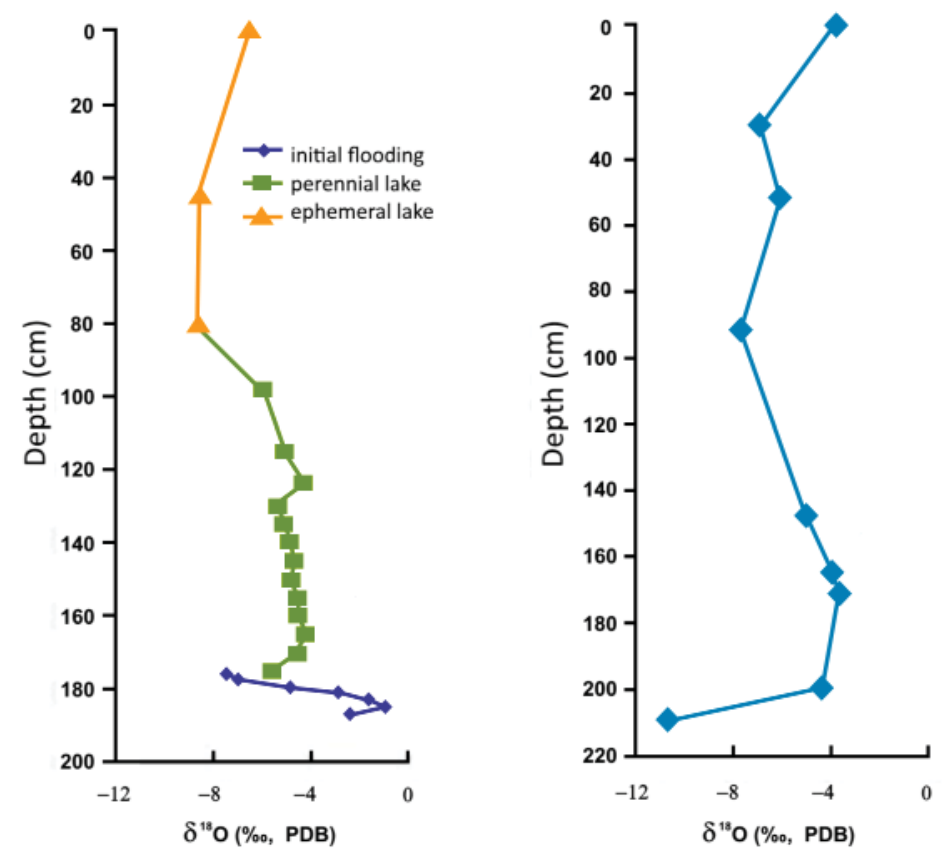

\section{Seasonally Connected Pool Clarias and Synodontis (Catfish)}
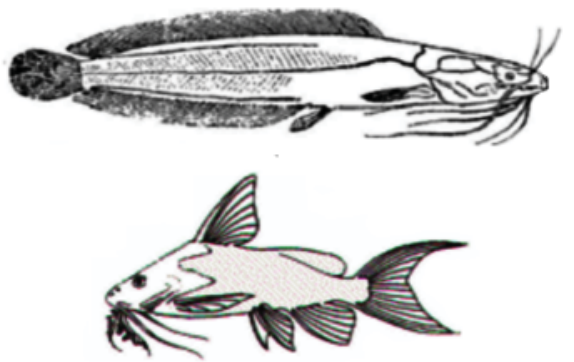

\section{Lates Niloticus (Nile Perch)}

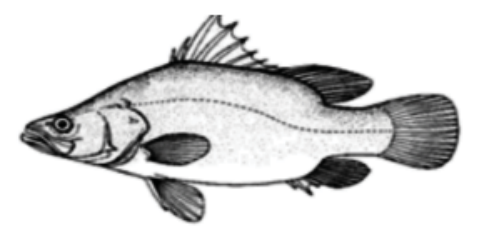

Fig. 17. Geochemistry for Late Pleistocene sub-basin north of BT-14 excavations, Trench 3/87 on the left, and Trench 3/86 on the right (locations of Trench 3/86 and Trench 3/87 are shown on Fig. 10). Examples of fish recovered from the Central Basin deposits.

provides evidence of four major episodes of limnic-related sedimentation within a deflational basin, separated by drier intervals associated with erosional unconformities.

\section{DISCUSSION}

A relative age model can be proposed based on the geomorphic/topographic context of the basin-fill sediments and taxonomic assignments of artifacts associated with the sequences. In addition, geochronometric studies of samples from the deposits provide an opportunity to correlate the Bir Tarfawi sequences with broader-scale paleoclimate patterns. The presence of Acheulian artifacts with the highest remnant located in the northeast part of the study area indicates that these deposits are the oldest. The elevation based-age model interprets the record as indicating an initial erosional event when local ground water levels were around $247 \mathrm{~m}$ a.s.l. (Fig. 18). A subsequent rise in the water-table led to the deposition of the sediments that form the northeast remnant (Figs 6-9). Another erosional episode led to the formation of a topographic low at $245 \mathrm{~m}$ a.s.l. that was subsequently filled with the deposits that form the northwest remnant at a time when water levels rose again (Figs 10, 11). A third deflational episode, caused by a drop in the water level to at least $242 \mathrm{~m}$ a.s.l., resulted in the formation of a topographic low that was subsequently filled with basin-fill sediments of the grey-green sequence (strata 1-4) sequence (Figs 12-17).

In terms of broader-scale correlations, insolation maxima and the dust and sapropel records from the eastern Mediterranean have been used to document wetter, savannah landscapes in northeast Africa that can be linked to changes in the summer monsoon (cf. Larrasona, 2012;
Larrasona et al., 2013). Middle Pleistocene wet episodes may have occurred around 330, 285, 240, 215, 195 and 170 $\mathrm{ka}$, while wetter conditions would have prevailed during the Late Pleistocene at around 125, 100 and $80 \mathrm{ka}$. For example, the $125 \mathrm{ka}$ wet period is connected to one of the highest boreal summer insolation maxima. Using probability density function analysis based on luminescence and uranium-series dates from North Africa, Drake and Breeze (2016) suggested that humid periods in Saharan North Africa centered on 129-92 ka and $76 \mathrm{ka}$. If these periods of humidity can correlate with the deposits at Bir Tarfawi, it would support the interpretation that the grey-green basin-fill sequence (strata $1-4$ ) reflects wet isotope stages 5e, 5c and 5a. Earlier Middle Pleistocene wet episodes could be associated with the northeast and northwest remnants.

Several potential sources for the Pleistocene waters at Bir Tarfawi have been postulated, including local rains, groundwater recharge associated with aquifers and migrating or intensified rain fronts, drainage within a catchment watershed, and connections to the Nile. Sources of water that could have contributed to the water bodies at Bir Tarfawi are associated with paleo-drainage systems delineated for southwestern Egypt and northwestern Sudan (Brinkmann et al., 1987; Abdelsamlam et al., 2000; Ghoneim and El-Baz, 2007; Youssef, 2009; Abdelkareem and El-Baz, 2015). These include waters flowing from the Uweinat uplift and the Gil Kebir mountains into the Bir Tarfawi region. The Pleistocene deposits at Bir Tarfawi have been used by Youssef (2009) as verification of an area of groundwater recharge resulting from infiltration of runoff from the watersheds to the west, such as the Gilf Kebir plateau and the Uweinat highlands. In a similar manner, Robinson et al. (2007) propose the kankar deposits in the Bir Tarfawi region can be explained by surface runoff 


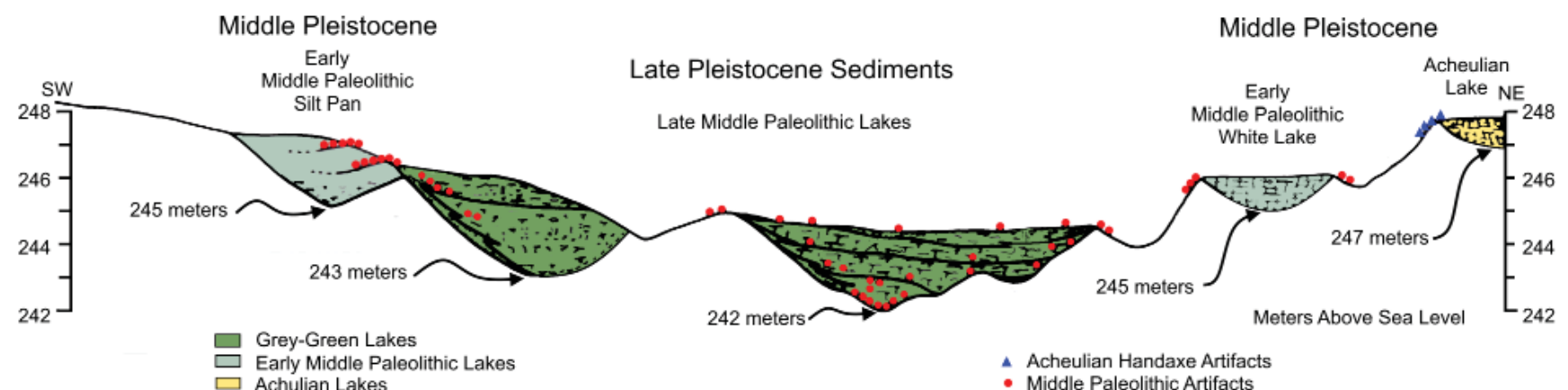

Fig. 18. Geomorphic context, elevations for study area serving as a basis for the age model.

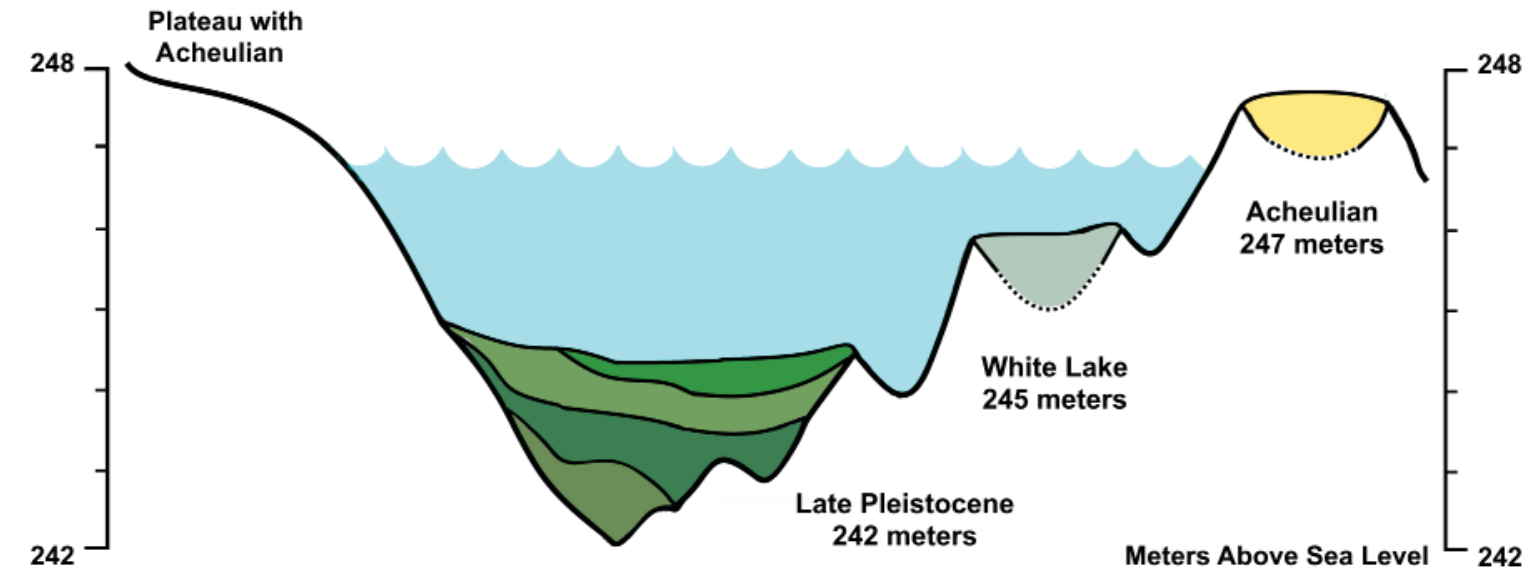

Fig. 19. Potential elevations of waterbody at $247 \mathrm{~m}$ a.s.l. relative to the three deflational basins (northeast remnant; northwest remnant; BT-14 (Bir Tarfawi Site 14) area and Central Basin).

that would have resulted in high groundwater levels during pluvial episodes. Potential groundwater flow into the Bir Tarfawi includes generally eastward flowing waters from Gilf Kebir and Gebel Oweinat and northeastward flows from northern Sudan (Brinkman et al., 1987).

In northern Sudan and southwest Egypt, groundwater elevations generate a contour pattern that slopes from southwest to the northeast (cf. Thorweihe and Heinl, 1990). While groundwater is at around $242 \mathrm{~m}$ a.s.l. at Bir Tarfawi, to the southwest it is at higher elevations but further below the surface. At the General Petroleum Camp southwest of Bir Tarfawi the groundwater elevation in 1980 was at $274 \mathrm{~m}$ a.s.l. at a depth below surface of $27 \mathrm{~m}$. To the east, at the Bir Safsaf waterhole the water is at the surface at an elevation of $226 \mathrm{~m}$ a.s.l., while the water level is at the surface at an elevation of $176 \mathrm{~m}$ a.s.l. at the Bir Kiseiba waterhole and at $205 \mathrm{~m}$ a.s.l. and at the surface at Bir Tackhlis. If a higher groundwater level and seasonal rains led to the formation of the water bodies at Bir Tarfawi, it might be expected that the relative pattern of groundwater elevation relationships occurring today would approximate the pattern prevailing during Pleistocene wet episodes.

Using a digital elevation models and ignoring any potential changes of topography due to episodic deflation during arid intervals, Maxwell et al. (2010) proposed the presence of vastly expanded Middle Pleistocene lakes in the TarfawiKiseiba-Tushka region of southern Egypt, including Bir
Tarfawi. Besides large Middle Pleistocene lakes, it was postulated that a regional mega-lake would have covered an area extending from the Sudan border north to the Kharga and Dakhla Oases during the Late Pleistocene (Maxwell et al., 2010). Bones of Nilotic fish (van Neer, 1993) recovered from the Central Basin sequence were used as evidence supporting the proposal of a Late Pleistocene SelimaTarfawi mega-lake forming a local base level at $247 \mathrm{~m}$ a.s.l. (Maxwell et al., 2010). The available sedimentological and stratigraphic field evidence from Bir Tarfawi indicates basin-fill deposition below $245 \mathrm{~m}$ a.s.l., so it is possible that at times the water level could have been around $247 \mathrm{~m}$ a.s.l. If the water level associated with the grey-green (strata 1-4) basin-fill reached $273 \mathrm{~m}$ a.s.l., it would have inundated the northwest "White Lake" sedimentary remnant (Fig. 19). There is no obvious evidence of sedimentary deposition at this remnant that can be attributed to a grey-green climate episode of inundation. Even at these hypothetical levels, the waterbody would likely still have been largely confined within the present-day deflational basin. For example, the floor of the plateau plain rises to the west of Bir Tarfawi to $253 \mathrm{~m}$ a.s.l. just east of the Bir Sahara area. In addition, the presence of a water level at $247 \mathrm{~m}$ a.s.l. at Bir Tarfawi would imply lower levels of groundwater to the east if the relative pattern of present-day groundwater contour relationships can serve as a model for Pleistocene groundwater elevation and flow. 


\section{CONCLUSION}

The sedimentologic and lithostratigraphic field evidence provides the means to infer depositional contexts associated with the three sets of basin-fills. For example, the stratigraphy and lithofacies examined support the presence of waterbodies that fluctuated in depth and aerial extent. For each of the three topographic lows, basin-fills can be interpreted on the basis of the sedimentology of the carbonate rocks and the textural properties of the clastic fractions. The limestones (micrites, soft chalky limestones or marls) may have precipitated in ponds or relative shallow lakes and marshes (cf. Hay et al., 1986). The secondary structures of the northeast remnant associated Acheulian artifacts (Fig. 6) suggest the possibility of either bioturbation in marsh settings or post-depositional modification, perhaps associated with subsequent fluctuations in the water table. While thick deposits of marl limestone imply the presence of perennially wet conditions at the deeper water areas, the fluctuating nature of the basin-edge shore area environments is evident for both the northwest "White Lake" and the grey-green (strata $1-4$ ) sequence. The basin-margin areas were alternately flooded and dried by episodic transgressions and regressions directly tied to available moisture levels. Stands of Phragmites in the shallow water near the shore or along the edge of the depositional basin as well as other vegetation surrounding the waterbody or within the catchment would have at times reduced any sediment wash into the basin. Lateral variation in clastic deposition helps to document the depositional facies within the basins, especially for the basin-fills associated with Middle Paleolithic artifacts (the northwest and Central Basin sequences). At times the landscapes associated with the water bodies may have resembled marshlands where there was open water and phreatophyte flats when the water table was further from the surface (cf. Quade, 1986; Quade et al., 1995).

Lowering of the water-table would terminate deposition within a basin, except for the deposition of clastics washed in by potential local rains and aeolian deposits. Major deflation events separate the depositional episodes within the three basins. The initial erosional surface for the northeast Acheulian remnant is $247 \mathrm{~m}$ a.s.l., the northwest remnant is $244 \mathrm{~m}$ a.s.l. (2.5 $\mathrm{m}$ below the Acheulian level), and the grey-green basin is ca. $242 \mathrm{~m}$ a.s.l. (2 $\mathrm{m}$ below the White Lake basin). During the Pleistocene the rise and fall of the water table, and thus the presence or absence of marshes, ponds, and relatively small and shallow lakes, was a result of groundwater recharge from regional-scale catchment areas to the west and south, and local rainfall.

The sedimentological and stratigraphic characteristics of the deposits in the north-central part of Bir Tarfawi demonstrate the presence of high groundwater levels that led to basin-fill sedimentation during wetter climate episodes. The sedimentary sequences and their topographic/ geomorphic context appear to provide information on the size and extent of waterbodies in southern Egypt during the Pleistocene. The depth and extent of the lakes fluctuated with the availability of groundwater derived from catchment recharge and local rains. Groundwater fed small lakes and marsh conditions are indicated by the sediments and the lithofacies variations of the basin-fill. The sediments and fossils provide information on episodic changes in late Quaternary depositional environments that can be correlated with regional-scale climate change and its impact on groundwater levels. These interpretations of the sedimentary deposits from north-central Bir Tarfawi provide a basis for evaluating various models that have been proposed regarding the nature of hydrologic and environmental conditions within this region of North Africa.

\section{Acknowledgments}

Field research was conducted as part of the Combined Prehistoric Expedition (Egyptian Geological Survey, Polish Academy of Sciences, Southern Methodist University). Sedimentological laboratory analyses were conducted at the University of Minnesota Duluth (Archaeometry Laboratory). Partially funded from National Science Foundation grants BNS-8415650, BNS-8518574, and BNS-8718908, the Sigma Xi, the Scientific Research Society, and the C.L. Matsch Fund for Geomorphic Research. Thank you to the reviewers whose suggestions improved the text. Special thanks to Cheryl Lynn Wofford Hill for drafting the final versions of the figures.

\section{REFERENCES}

Abell, P., Hoelzmann, P., 2000. Holocene paleoclimates in northwestern Sudan: stable isotope studies on molluscs. Global and Planetary Change 26, 1-12.

Abdelkareem, M., El-Baz, F., 2015. Regional view of a trans-African drainage system. Journal of Advanced Research 6, 433-439.

Abdelsalam, M., Robinson, C., El-Baz, F., Stern, R., 2000. Applications of orbital imaging radar for geologic studies in arid regions: the Saharan testimony. Photogrammetric Engineering Remote Sensing 66, 717-726.

Alaily, F., 1993. Soil association and land suitability maps of the Western Desert, SW Egypt. Catena Supplement 26, 123-153.

Bagnold, R.A., 1933. A further journey through the Libyan Desert. Geographical Journal 82, 103-129, 211-235.

Behrens, J. Burkhardt, H., Erbas, K., Fiedler-Volmer, R., Kalkbrenner, M., Lorenz, B., and Schulz-Ohlberg, J., 1984. Geophysical investigations in the arid regions of SW Egypt and NW Sudan. Berliner geowissenschaftlichen Abhandlungen (A) 40, 441-457.

Bradbury, C., Hill, C., 2008. Variability in a Pleistocene climate sequence from Bir Tarfawi, Egypt. Proceedings of the $50^{\text {th }}$ Annual Meeting of the Idaho Academy of Sciences, 1-11.

Brinkmann, P., Heinl, M., Hollander, R., Reich, G., 1987. Retrospective simulation of groundwater flow and transport in the Nubia Aquifer system. Berliner geowissenschaftlichen Abhandlungen (A) 75.2, 465-516.

Drake, N. Breeze, P., 2016. Climate change and modern human occupation of the Sahara from MIS 6-2. In: Jones, S., Stewart, A (Eds), Africa from MIS 6-2: Population Dynamics and Paleoenvironments, 103-122, Springer.

De Deckker, P., Williams, M., 1993. Lacustrine paleoenvironments of the area of Bir Tarfawi-Bir Sahara East reconstructed from fossil ostracods and the chemistry of their shells. In: Wendorf, F., Schild, R.., Close, A. (Eds), Egypt During the Late Interglacial, 115-119, Plenum, New York.

Gautier, A., 1993. The Middle Paleolithic archaeofaunas from Bir Tar- 
fawi (Western Desert, Egypt). In: Wendorf, F., Schild, R., Close, A. (Eds), Egypt During the Late Interglacial, 121-143, Plenum, New York.

Ghoneim, E., El-Baz, F., 2007. The application of radar topographic data to the mapping of a mega-paleodrainage in the Eastern Sahara. Journal of Arid Environments 69, 658-675.

Hay, R.,Pexton, R., Teague, T., Kyser, T., 1986. Spring related carbonate rocks, Mg-clays, and associated minerals in Pliocene deposits of the Amargosa Desert, Nevada and California. Geological Society of America Bulletin 97, 1488-1503.

Hesse, K., Hissene, A., Kheir, O., Schnacker, M., Schneider, Thorweithe, U., 1987. Hydrological investigations in the Nubian aquifer system, Eastern Sahara. Berliner geowissenschaftlichen Abhandlungen (A) 75(2), 397-464.

Hill, C. 1992. Archaeological and Pleistocene Geology of Acheulian and Middle Paleolithic Sites in the Bir Tarfawi Region of the Southern Egyptian Sahara. Ph.D. Dissertation, Southern Methodist University, Dallas.

Hill, C., 2001. Geologic contexts of the Acheulian (Middle Pleistocene) in the Eastern Sahara. Geoarchaeology 16(1), 65-94.

Hill, C. 2002. Archaeological geology of the Abbasianian, Saharan, and Nabtan Pluvials: Chronologic status of Quaternary climate-stratigraphic units in Egypt. Geological Society of America Abstracts with Programs 34(6), 183.

Issawi, B., 1978. Quaternary geology of Bir Sahara, Western Desert, Egypt. Annals of the Geological Survey of Egypt 8, 295-304.

Issawi, B., 1993. Contribution to the stratigraphy of the area of Bir Tarfawi and Bir Sahara East. In: Wendorf, F., Schild, R. Close, A. (Eds), Egypt During the Late Interglacial, 211-2214, Plenum, New York.

Issawi, B., Hinnawi, M, Francis, M., Mazhar, A., 1999. The Phanerozoic Geology of Egypt: A Geodynamic Approach, Egyptian Geological Survey, Cairo.

Kehl, H., 1987. Zonation and establishment of vegetation in selected uninhabited Egyptian and Sundanese oasis. Catena 14, 275-290.

Klitzsch, E., 1983. Geological research in and around Nubia. Episodes 3, 15-19.

Kowalski, K., Van Neer, W., Bochenski, Z., Mlynarski, M., Rzebik-Kowalska, B., Szyndlar, A., Gautier, Schild, R., Close, A., Wendorf, F., 1989. A Last Interglacial fauna from the Eastern Sahara. Quaternary Research 32, 335-341.

Kropelin, S., 1993. Geomorphology, landscape evolution and paleoclimates of southwest Egypt. Catena Supplement 26, 31-65.

Larrasona, J., 2012., A northeastern Saharan perspective on environmental variability in North Africa and its implications for modern human origins. In: Hublin, J., McPherron, S. (Eds), Modern Origins: A North African Perspective, 19-34, Springer, New York.

Larrasona, J., Roberts, A., Rohling, E., 2013. Dynamics of Green Sahara Periods and their role in hominin evolution. PLOS ONE 8 (10), $1-12$.

Maxwell, T., Issawi, B., Haynes, C., Jr., 2010. Evidence for Pleistocene lakes in the Tushka region, south Egypt. Geology 38 (12), 1135-1138.

McKenzie, J., 1993a. Pluvial conditions in the eastern Sahara following the penultimate deglaciation: implications for changes in atmospheric circulation patterns with global warming. Palaeogeography, Palaeoclimatology, Palaeoecology 103, 95-105.

McKenzie, J., 1993b. Chemical stratigraphy of lacustrine sequences deposited during latest Pleistocene pluvial periods in the Eastern Sahara. In: Wendorf, F., Schild, R. Close, A. (Eds), Egypt During the Late Interglacial, 106-114, Plenum, New York.
McKinney, C., 1993. Bir Tarfawi: A stratigraphic test of uranium-series dating of tooth enamel. In: Wendorf, F., Schild, R. Close, A. (Eds), Egypt During the Late Interglacial, 218-223, Plenum, New York.

Pachur, H., Roper, H., Kropelin, S., Goschin, M., 1987. Late Quaternary hydrogeography of the Eastern Sahara. Berliner geowissenschaftlichen Abhandlungen (A) 75, 331-384.

Quade, J., 1986. Late Quaternary environmental changes in the upper Las Vegas Valley. Quaternary Research 26: 340-357.

Quade, J., Mifflin, M., Pratt, W., McCoy, W., Burckle, L., 1995. Fossil spring deposits in the southern Great Basin and their implications for changes in water-table levels near Yucca Mountain, Nevada, during Quaternary time. Geological Society of America Bulletin 107 (2), 213-230.

Richter, A., Schandelmeier, H., 1990. Precambrian basement inliers of Western Desert geology, petrology and structural evolution. In: Said, R. (Ed.), The Geology of Egypt, 185-200, Balkema, Rotterdam.

Roper, H., 1993. Calcretes in the Western Desert of Egypt. In: Thorweihe, Schandelmeier (Eds), Geoscientific Research in Northeast Africa, 635-639, Balkema, Rotterdam.

Said, R., 1990. Quaternary. In: Said, R. (Ed.), The Geology of Egypt, 487-507, Balkema, Rotterdam.

Schild, R., Wendorf, F., 1981. The Prehistory of an Egyptian Oasis. Ossolineum, Wroclaw, Poland.

Schild, R., Wendorf, F., 1993. Middle Paleolithic lakes in the southwestern Desert of Egypt. In: Wendorf, F., Schild, R. Close, A. (Eds), Egypt During the Late Interglacial, 15-65, Plenum, New York.

Schneider, U., 1993. Phytomass, element and water relations of wild and cultivated plants in the Western Desert of SW Egypt. Catena Supplement 26, 179-199.

Schwarcz, H., Morawska, L., 1993. Uranium-series dating of carbonates from Bir Tarfawi and Bir Sahara East. In: Wendorf, F., Schild, R., Close, A. (Eds), Egypt During the Late Interglacial, 205-217, Plenum, New York.

Szabo, B., Haynes, C., Maxwell, T., 1995. Ages of Quaternary pluvials determined by uranium-series and radiocarbon dating of lacustrine deposits of Eastern Sahara. Palaeogeography, Palaeoclimatology, Palaeoecology 113, 227-242.

Szabo, B., McHugh, W., Haynes, C., Schaber, G., Breed, C., 1989. Uranium-series dated authigenic carbonates and Acheulian sites in southern Egypt. Science 243, 1053-1056.

Thorweighe, U., Heinl, M., 1990. South-West Egypt 1: Hydrology. Geopotential Maps of the Western Desert of Egypt. Geopotential and Ecology, Catena Supplement 26.

Van Neer, W., 1993. Fish remains from the Last Interglacial at Bir Tarfawi (Eastern Sahara, Egypt). In: Wendorf, F., Schild, R. Close, A. (Eds), Egypt During the Last Interglacial, 144-154, Plenum New York.

Wendorf, F., Schild, R. Close, A. (Eds), 1993. Egypt During the Late Interglacial, Plenum, New York.

Wendorf, F., Schild, R., Close, A., Schwarcz, H., Miller, G., Grun, R.,Bluszcz, A., Stokes, S., Morawski, L., Huxtable, J., Hill, C., McKinney, C., 1994. A chronolology for the middle and late Pleistocene wet episodes in the Eastern Sahara. In: Bar-Yosef, O., Kra, R. (Eds), Late Quaternary chronology and paleoclimates of the Eastern Mediterranean, 147-168, Radiocarbon, Tucson, Arizona.

Youssef, A., 2009. Mapping the mega paleodrainage basin using the shuttle radar topography mission in the eastern Sahara and its impact on the new development projects in southern Egypt. Geo-spatial Information Science 12 (3), 182-190. 